University of Nebraska - Lincoln

DigitalCommons@University of Nebraska - Lincoln

\title{
Biochemical Effects of Lead, Zinc, and Cadmium from Mining on Fish in the Tri-States District of Northeastern Oklahoma, USA
}

Christopher J. Schmitt

U.S. Geological Survey, cjschmitt@usgs.gov

Jeffrey J. Whyte

ASci Corporation

William G. Brumbaugh

United States Geological Survey, bbrumbaugh@usgs.gov

Donald E. Tillitt

U.S. Geological Survey, dtillitt@usgs.gov

Follow this and additional works at: https://digitalcommons.unl.edu/usgsstaffpub

Schmitt, Christopher J.; Whyte, Jeffrey J.; Brumbaugh, William G.; and Tillitt, Donald E., "Biochemical Effects of Lead, Zinc, and Cadmium from Mining on Fish in the Tri-States District of Northeastern Oklahoma, USA" (2005). USGS Staff -- Published Research. 567.

https://digitalcommons.unl.edu/usgsstaffpub/567

This Article is brought to you for free and open access by the US Geological Survey at DigitalCommons@University of Nebraska - Lincoln. It has been accepted for inclusion in USGS Staff -- Published Research by an authorized administrator of DigitalCommons@University of Nebraska - Lincoln. 


\title{
BIOCHEMICAL EFFECTS OF LEAD, ZINC, AND CADMIUM FROM MINING ON FISH IN THE TRI-STATES DISTRICT OF NORTHEASTERN OKLAHOMA, USA
}

\author{
Christopher J. Schmitt, $* \dagger$ Jeff J. Whyte, $\$$ William G. Brumbaugh, $\dagger$ and Donald E. Tillitt $\dagger$ \\ $\dagger$ U.S. Geological Survey, Columbia Environmental Research Center, \\ \$ASci Corporation, c/o U.S. Geological Survey-Columbia Environmental Research Center, 4200 New Haven Road, \\ Columbia, Missouri 65201
}

(Received 1 July 2004; Accepted 7 December 2004)

\begin{abstract}
We assessed the exposure of fish from the Spring and Neosho Rivers in northeast Oklahoma, USA, to lead, zinc, and cadmium from historical mining in the Tri-States Mining District (TSMD). Fish $(n=74)$ representing six species were collected in October 2001 from six sites on the Spring and Neosho Rivers influenced to differing degrees by mining. Additional samples were obtained from the Big River, a heavily contaminated stream in eastern Missouri, USA, and from reference sites. Blood from each fish was analyzed for $\mathrm{Pb}, \mathrm{Zn}, \mathrm{Cd}, \mathrm{Fe}$, and hemoglobin $(\mathrm{Hb})$. Blood also was analyzed for $\delta$-aminolevulinic acid dehydratase (ALA-D) activity. The activity of ALA-D, an enzyme involved in heme synthesis, is inhibited by $\mathrm{Pb}$. Concentrations of Fe and Hb were highly correlated $(r=0.89, p<0.01)$ across all species and locations and typically were greater in common carp (Cyprinus carpio) than in other taxa. Concentrations of $\mathrm{Pb}, \mathrm{Zn}$, and $\mathrm{Cd}$ typically were greatest in fish from sites most heavily affected by mining and lowest in reference samples. The activity of ALA-D, but not concentrations of $\mathrm{Hb}$ or Fe, also differed significantly ( $p$ $<0.01)$ among sites and species. Enzyme activity was lowest in fish from mining-contaminated sites and greatest in reference fish, and was correlated negatively with $\mathrm{Pb}$ in most species. Statistically significant $(p<0.01)$ linear regression models that included negative terms for blood $\mathrm{Pb}$ explained as much as $68 \%$ of the total variation in ALA-D activity, but differences among taxa were highly evident. Positive correlations with $\mathrm{Zn}$ were documented in the combined data for channel catfish (Ictalurus punctatus) and flathead catfish (Pylodictis olivaris), as has been reported for other taxa, but not in bass (Micropterus spp.) or carp. In channel catfish, ALA-D activity appeared to be more sensitive to blood $\mathrm{Pb}$ than in the other species investigated (i.e., threshold concentrations for inhibition were lower). Such among-species differences are consistent with previous studies. Enzyme activity was inhibited by more than 50\% relative to reference sites in channel catfish from several TSMD sites. Collectively, our results indicate that $\mathrm{Pb}$ is both bioavailable and active biochemically in the Spring-Neosho River system.
\end{abstract}

Keywords-Metals Mining Iron $\quad \delta$-Aminolevulinic acid dehydratase activity Hemoglobin

\section{INTRODUCTION}

The Tri-States Mining District (TSMD) of Missouri, Kansas, and Oklahoma, USA, was mined extensively for zinc, lead, and other metals from the mid-1800s through the 1950s. Lead, $\mathrm{Zn}$, and cadmium, which can be toxic to aquatic organisms and wildlife, have been released from historical mining and related activities and have contaminated surface waters, groundwater, stream sediments, and biota in parts of the Spring River (SR) and Neosho River (NR) and their tributaries [15]; Fig. 1). Effects on human health from exposure to miningderived metals have been documented [6], as have biochemical and ecological effects on aquatic biota $[4,7]$.

Relative to the Missouri and Kansas portions of the TSMD, metals contamination of aquatic resources in northeastern Oklahoma has received limited study. The objectives of this investigation, therefore, were to obtain preliminary information on the exposure of fish in the Oklahoma portions of the TSMD to metals from mining and to document effects of such exposure. These objectives were achieved by collecting and analyzing blood samples of several species of fish for $\mathrm{Pb}, \mathrm{Zn}$, and $\mathrm{Cd}$. Because of the well-known effects of $\mathrm{Pb}$ on heme synthesis and iron metabolism, the blood samples also were analyzed for hemoglobin $(\mathrm{Hb}), \mathrm{Fe}$, and the activity of the enzyme $\delta$-aminolevulinic acid dehydratase (ALA-D, also known as porphobilinogen synthetase; Enzyme Commission

* To whom correspondence may be addressed (cjschmitt@usgs.gov).
4.2.1.24; http://www.ebi.ac.uk/intenz/index.html). This enzyme catalyzes the condensation of porphobilinogen (PBG), a heme precursor, from aminolevulinic acid and is inhibited by $\mathrm{Pb}[8,9]$. The enzyme also requires $\mathrm{Zn}$ as a cofactor; $\mathrm{Pb}$ induced ALA-D inhibition is caused by the displacement of $\mathrm{Zn}$ from the metal-binding site and a resulting change in quarternary structure [9]. Erythrocyte ALA-D activity can readily be measured and represents a well-documented biomarker of $\mathrm{Pb}$ exposure in fish [4,10-17], birds [18], mammals [19,20], and reptiles [21]. Lead also inhibits ferrochelatase (protoheme ferrolyase, Enzyme Commission 4.99.1.1; http://www.ebi.ac. uk/intenz/index.html), which catalyzes the insertion of $\mathrm{Fe}^{2+}$ into protoporphyrin IX to form heme [8]. Inhibition ultimately may cause porphyria, anemia, or both $[8,20]$. In this paper we report the results of analyses of fish blood from the Oklahoma waters of the TSMD for metals, ALA-D activity, and $\mathrm{Hb}$ as indicators of contamination from historical mining and related activities.

\section{METHODS OF STUDY}

\section{Collection sites, species, and field procedures}

Mining-derived contaminants enter the SR from flowing mines and former ore-processing and tailings-disposal sites in Missouri, Kansas, and Oklahoma (Fig. 1). In Oklahoma, these sources are concentrated in the area drained by Tar Creek (TC), a tributary of the NR (Fig. 1). Collection sites $(n=6)$ were selected to bracket the range of exposure conditions present 


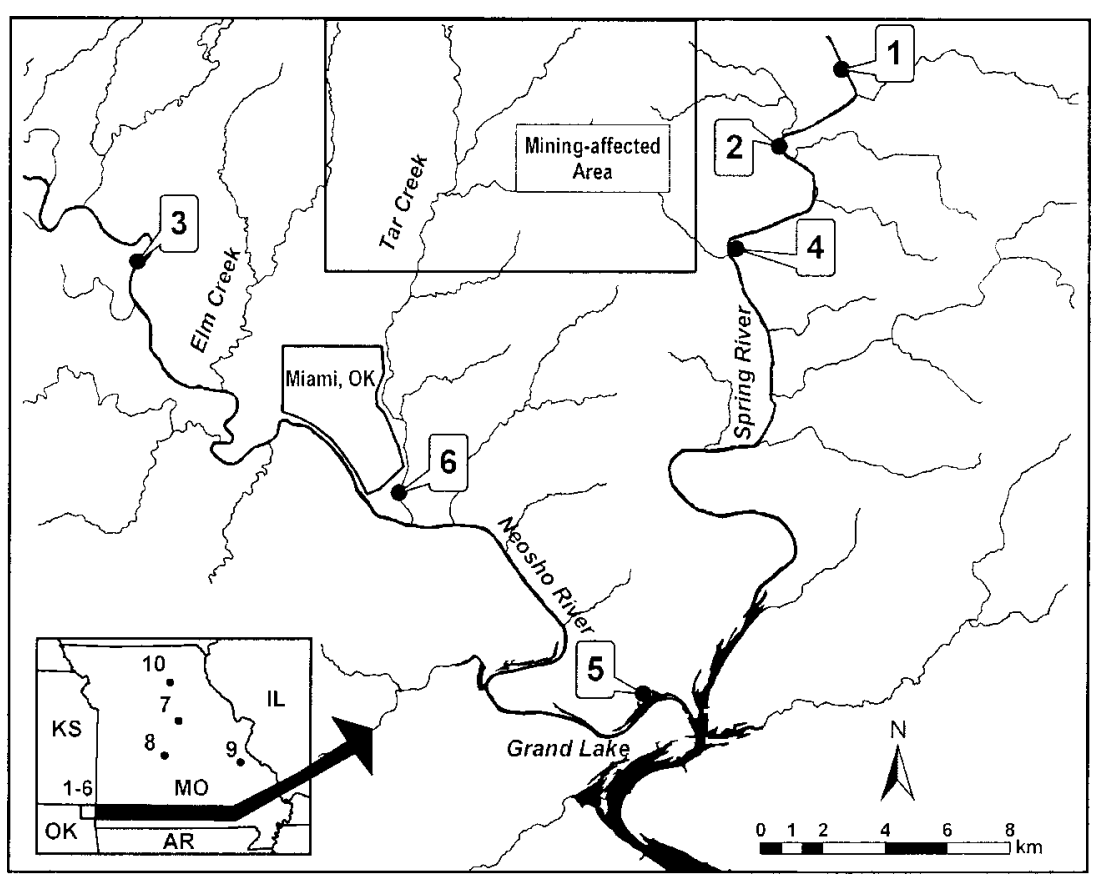

Fig. 1. Map of northeastern Oklahoma, USA, showing the location of collection sites (1-6) on the Spring and Neosho Rivers. Also shown is the general boundary of the mining-affected area in the Tar Creek watershed (rectangle) and the reference and positive control sites (7-10) in Missouri (inset). Additional mining-affected areas are drained by the Spring River in Kansas and Missouri, USA, upstream (north and northeast) of the area shown in detail.

in TSMD-affected portions of the SR and NR in Oklahoma. Two sites were located on each of the SR and NR upstream of their confluence in Grand Lake. The other two were located within Grand Lake and in the lower reaches of TC (Fig. 1, Table 1). One NR site (Site 3) was upstream of known TSMD pollution sources (Fig. 1, Table 1). Fish were collected by electrofishing at all TSMD sites in October 2001. The collection target was four specimens of each of three primary species at each site: Common carp (Cyprinus carpio, henceforth carp), largemouth bass (Micropterus salmoides), and channel catfish (Ictalurus punctatus). Spotted bass (Micropterus punctulatus), white crappie (Pomoxis annularis, henceforth crappie), or both were substituted for largemouth bass, and flathead catfish (Pylodictis olivaris) were substituted for channel catfish when sufficient numbers of the primary species could not be obtained.

Few studies of ALA-D inhibition by $\mathrm{Pb}$ have been conducted with the fish used in this study, and there is considerable

Table 1. Sites in Missouri (MO) and Oklahoma (OK), USA, from which fish were collected. Also shown are collection dates and water temperatures

\begin{tabular}{|c|c|c|c|c|c|}
\hline $\begin{array}{l}\text { Site } \\
\text { no. }\end{array}$ & Water body and location & County (State) & Date & $\begin{array}{l}\text { Latitude, } \\
\text { longitude }^{\text {a }}\end{array}$ & $\begin{array}{l}\text { Water } \\
\text { temperature } \\
\text { (C) }\end{array}$ \\
\hline 1 & Spring River near OK state line & Ottawa (OK) & $10 / 15 / 01$ & $\begin{array}{l}36^{\circ} 59^{\prime} 50.5^{\prime \prime} \mathrm{N} \\
94^{\circ} 42^{\prime} 37.4^{\prime \prime} \mathrm{W}\end{array}$ & 15.4 \\
\hline 2 & Spring River at Blue Hole & Ottawa (OK) & $10 / 15 / 01$ & $\begin{array}{l}36^{\circ} 57^{\prime} 41.0^{\prime \prime} \mathrm{N} \\
94^{\circ} 43^{\prime} 20.6^{\prime \prime} \mathrm{W}\end{array}$ & 15.4 \\
\hline 3 & Neosho River at Stepps Ford Bridge & Ottawa (OK) & $10 / 16 / 01$ & $\begin{array}{l}36^{\circ} 53^{\prime} 25.0^{\prime \prime} \mathrm{N} \\
94^{\circ} 55^{\prime} 38.5^{\prime \prime} \mathrm{W}\end{array}$ & 14.0 \\
\hline 4 & Spring River at Promenade Bridge & Ottawa $(\mathrm{OK})$ & $10 / 16 / 01$ & $\begin{array}{l}36^{\circ} 56^{\prime} 01.1^{\prime \prime} \mathrm{N} \\
94^{\circ} 44^{\prime} 40.9^{\prime \prime} \mathrm{W}\end{array}$ & 13.0 \\
\hline 5 & Neosho River at Twin Bridges (Grand Lake) & Ottawa (OK) & $10 / 16 / 01$ & $\begin{array}{l}36^{\circ} 47^{\prime} 56.0^{\prime \prime} \mathrm{N} \\
94^{\circ} 45^{\prime} 18.5^{\prime \prime} \mathrm{W}\end{array}$ & 16.1 \\
\hline 6 & Tar Creek at Neosho River & Ottawa (OK) & $10 / 17 / 01$ & $\begin{array}{l}36^{\circ} 51^{\prime} 25.7^{\prime \prime} \mathrm{N} \\
94^{\circ} 51^{\prime} 39.2^{\prime \prime} \mathrm{W}\end{array}$ & ND \\
\hline 7 & USGS-CERC $^{\mathrm{b}}$ (reference) & Boone (MO) & $10 / 22 / 01$ & $\begin{array}{l}38^{\circ} 54^{\prime} 41.5^{\prime \prime} \mathrm{N} \\
92^{\circ} 16^{\prime} 58.0^{\prime \prime} \mathrm{W}\end{array}$ & 18.0 \\
\hline 8 & Osage Catfisheries (reference) & Camden (MO) & $10 / 23 / 01$ & $\begin{array}{l}38^{\circ} 07^{\prime} 38.9^{\prime \prime} \mathrm{N} \\
92^{\circ} 40^{\prime} 54.5^{\prime \prime} \mathrm{W}\end{array}$ & 17.0 \\
\hline 9 & $\begin{array}{l}\text { Big River at St. Francois State Park } \\
\text { (positive control) }\end{array}$ & St. Francois (MO) & $12 / 07 / 01$ & $\begin{array}{l}37^{\circ} 57^{\prime} 23.1^{\prime \prime} \mathrm{N} \\
90^{\circ} 32^{\prime} 29.5^{\prime \prime} \mathrm{W}\end{array}$ & 12.0 \\
\hline 10 & Long Branch Lake (reference) & Macon (MO) & $07 / 10 / 03$ & $\begin{array}{l}39^{\circ} 46^{\prime} 00.0^{\prime \prime} \mathrm{N} \\
92^{\circ} 31^{\prime} 0.00^{\prime \prime} \mathrm{W}\end{array}$ & 28.0 \\
\hline
\end{tabular}

${ }^{\text {a }}$ From geological positioning system, datum = World Geodetic System, 1984.

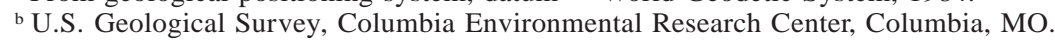


variation among taxa $[12,16]$. Therefore, reference fish from putatively uncontaminated sites and positive controls from a known contaminated site also were analyzed. Reference fish included largemouth bass and channel catfish from our laboratory and from a commercial source (Osage Catfisheries, Osage Beach, MO, USA) obtained and processed contemporaneously with the fish from Oklahoma. Positive controls were carp, largemouth bass, and spotted bass collected by electrofishing from the Big River (BR) in St. Francois County, Missouri, USA in early December 2001 (Fig. 1, Table 1). Elevated metal concentrations and inhibited ALA-D activity have been reported in fish and other biota from the BR, which is heavily contaminated by mine tailings $[4,5,17,21,22]$. Reference carp were obtained by electrofishing in July 2003 from Long Branch Lake (LB), a multiuse impoundment in rural Macon County, Missouri, USA (Fig. 1, Table 1). Concentrations of $\mathrm{Pb}$ and $\mathrm{Cd}$ in carp and other fish from LB historically have been low, but $\mathrm{Zn}$ has not been measured (unpublished monitoring data obtained in June 2003 from the Missouri Department of Conservation, Columbia, MO, USA).

Fish were transported alive to a central location and held in ambient water until they were processed, generally within 4 to $12 \mathrm{~h}$ of capture. Blood (nominally $1-5 \mathrm{ml}$ depending on fish species and size) was obtained from each fish by caudal veinipuncture using a chilled, heparinized $(6 \mathrm{IU} / \mathrm{ml})$ disposable needle and syringe. After removing the needle, one drop of blood was dispensed onto a clean piece of Parafilm $\mathrm{M}^{\circledR}$ (American National Can, Menasha, WI, USA) and analyzed immediately for $\mathrm{Hb}$ with a HemoCue ${ }^{\circledR}$ (HemoCue AB, Ängelholm, Sweden) portable blood photometer, which incorporates a microscale version of the azide-methemoglobin method [23]. About 0.2 to $0.5 \mathrm{ml}$ was next dispensed into a preweighed, acid-cleaned, 10-ml borosilicate glass test tube fitted with a Teflon ${ }^{\circledR}$-lined polyethylene screw cap. This subsample was frozen immediately in dry ice for analysis of metals by inductively coupled plasma mass spectrometry [2]. The remainder of the blood was dispensed into a 5-ml Cryovial ${ }^{\circledR}$ (Corning, Corning, NY, USA) and also frozen immediately in dry ice for analysis of ALA-D activity.

Following blood collection, the fish was subdued with a blow to the head, weighed $(\mathrm{g})$, and measured (total length $[\mathrm{mm}]$ ). A scale sample (if present) was obtained for age determination. The abdominal cavity of each fish was dissected and its gender was determined by gonadal observation. Upon return to the laboratory, blood samples to be analyzed for metals were stored frozen $\left(-20^{\circ} \mathrm{C}\right.$ for metals, $-80^{\circ} \mathrm{C}$ for ALA$\mathrm{D}$ activity) until prepared for analysis. Fish scales were dried and read with the aid of a dissecting microscope, with age $(y)$ estimated as the number of completed annuli.

\section{Temperature study}

During July 2003 the waters of LB were warmer than those from which the fish had been collected from the other sites in Fall 2001 (Table 1). The effects of temperature on ALA-D activity in fish have not been reported, but acclimation temperature is known to influence the rates of other enzyme-mediated processes [24]. To evaluate the effects of acclimation temperature on ALA-D activity, the LB fish $(n=16)$ were transported alive in ambient water to the laboratory and cooled gradually over a 7-d period. Six fish were processed immediately upon arrival $\left(28^{\circ} \mathrm{C}\right)$. The remainder were transferred to outdoor holding tanks supplied with well water from which four were removed and processed after $5 \mathrm{~d}\left(25^{\circ} \mathrm{C}\right)$ and $7 \mathrm{~d}$ $\left(21.5^{\circ} \mathrm{C}\right)$. All fish from LB were analyzed for ALA-D activity and $\mathrm{Hb}$, but blood metals were measured only in the fish sacrificed on the day of capture. Enzyme activity in carp from LB did not differ significantly $(p>0.05)$ among the three time-temperature periods evaluated. In contrast, Hb concentrations averaged $7.9 \mathrm{~g} / \mathrm{dL}$ on day $0,6.6 \mathrm{~g} / \mathrm{dL}$ on day 5 , and $8.9 \mathrm{~g} / \mathrm{dL}$ on day 7 (analysis of variance $F_{2,12}=5.58, p<$ 0.05). Because there were neither significant ALA-D differences nor clearly evident $\mathrm{Hb}$ trends, the day-0 data from LB ( $n=5$; the small volume of blood obtained from one fish injured during collection was not analyzed) were included in the larger data set for analysis.

\section{Laboratory methods}

Elemental contaminants and moisture content. Frozen blood samples were weighed in their tubes, freeze-dried, and reweighed, then digested in their tubes at room temperature by adding $1.0 \mathrm{ml}$ of concentrated, sub-boiling, distilled $\mathrm{HNO}_{3}$. After $1 \mathrm{~h}$, they were heated for $30 \mathrm{~min}$ at $110^{\circ} \mathrm{C}$, cooled for $15 \mathrm{~min}$, and $0.2 \mathrm{ml}$ of high-purity $\mathrm{H}_{2} \mathrm{O}_{2}$ was added. The samples then were reheated at $110^{\circ} \mathrm{C}$ for $30 \mathrm{~min}$, cooled again, and diluted to $10 \mathrm{ml}$ with ultrapure $\mathrm{H}_{2} \mathrm{O}$ for analysis by inductively coupled plasma mass spectrometry using a PE/ SCIEX Elan 6000 (Perkin-Elmer Instrument, Norwalk, CT, USA) equipped with a software-controlled CETAC ASX-500/ ADX-100 autosampler/autodiluter (CETAC Technologies, Omaha, NE, USA) [2]. The instrument was programmed to quantify the following masses: ${ }^{54} \mathrm{Fe}$ and ${ }^{57} \mathrm{Fe},{ }^{66} \mathrm{Zn}$ and ${ }^{68} \mathrm{Zn}$, ${ }^{111} \mathrm{Cd}$ and ${ }^{114} \mathrm{Cd}$, and $\mathrm{Pb}$ as the sum of three masses $\left({ }^{206} \mathrm{~Pb}+\right.$ $\left.{ }^{207} \mathrm{~Pb}+{ }^{208} \mathrm{~Pb}\right)$. All digestates were analyzed with 10 -times autodilution. Samples with a concentration exceeding the upper calibration standard for any element were further diluted by 10 -fold in serial fashion until all concentrations were within the range of the calibration standards.

For each group of samples analyzed, quality control measures incorporated at the digestion stage included tissue blanks, certified reference materials, replicates, and fortified samples (spikes). Instrumental quality control included periodic analysis of calibration check solutions, laboratory-control solutions, duplicate digestate analyses, analysis spikes, and interference checks; all were within acceptable limits.

Elemental concentrations were reported in both dry-weight (dry wt) and wet-weight (wet wt) units, the latter based on moisture loss of each sample during lyophilization. Method limits of detection (LODs) were calculated assuming a digestion of $50 \mathrm{mg}$ of dry blood and $85 \%$ moisture. The LOD ranges were Fe 1 to $60 \mu \mathrm{g} / \mathrm{g}$ dry weight, 0.2 to $9.0 \mu \mathrm{g} / \mathrm{g}$ wet weight; $\mathrm{Zn} 0.3$ to $5 \mu \mathrm{g} / \mathrm{g}$ dry weight, 0.04 to $0.8 \mu \mathrm{g} / \mathrm{g}$ wet weight; Cd 0.002 to $0.009 \mu \mathrm{g} / \mathrm{g}$ dry weight, 0.0003 to $0.001 \mu \mathrm{g} / \mathrm{g}$ wet weight; and $\mathrm{Pb} 0.004$ to $0.02 \mu \mathrm{g} / \mathrm{g}$ dry weight, 0.0006 to 0.003 $\mu \mathrm{g} / \mathrm{g}$ wet weight.

$A L A-D$ activity. Enzyme activity was assayed in 96-well microtiter plates using a procedure adapted from [25] and [12]. Each sample was analyzed in triplicate. For quality control purposes, one triplicate sample per plate was selected randomly for duplicate analysis in a separate location on the plate. Blood samples stored at $-80^{\circ} \mathrm{C}$ were thawed at $0^{\circ} \mathrm{C}$ and vortexed immediately before analysis. Into each of three microcentrifuge tubes containing either $25 \mu \mathrm{l}$ of cold $0.2 \%$ Triton $\mathrm{X}-100$ in $0.1-\mathrm{M}$ phosphate buffer solution ([PBS]; blank) or $25 \mu \mathrm{l}$ of cold $0.2 \%$ Triton $\mathrm{X}-100$ in $0.1-\mathrm{M}$ PBS containing $670 \mu \mathrm{g} / \mathrm{ml}$ of $\delta$-aminolevulinic acid-HCl, was added $5 \mu \mathrm{l}$ of whole blood homogenate. Samples were vortexed for $5 \mathrm{sec}$ 
and incubated at $37^{\circ} \mathrm{C}$ for $1 \mathrm{~h}$. The reactions were terminated with the addition of $200 \mu \mathrm{l}$ of trichloroacetic acid/N-ethylmaleimide solution $(4.0 \mathrm{~g}$ trichloroacetic acid and $2.7 \mathrm{~g} \mathrm{~N}$ ethylmaleimide per $100 \mu \mathrm{l}$ of $\mathrm{H}_{2} \mathrm{O}$ ) [19]. Tubes were centrifuged at $1,000 \times g$ for $5 \mathrm{~min}$ and $100 \mu \mathrm{l}$ of the supernatant was transferred in triplicate to a 96-well plate. Each well received $100 \mu \mathrm{l}$ of freshly prepared modified Ehrlich's reagent (3 $\mathrm{ml} \mathrm{d \textrm {H } _ { 2 }} \mathrm{O}, 42 \mathrm{ml}$ glacial acetic acid, $10 \mathrm{ml} 70 \%$ perchloric acid, $1 \mathrm{~g} p$-dimethylamino benzaldehyde). Each plate also contained an eight-point PBG standard curve (final concentration range in the wells was $0-221 \mu \mathrm{M}$ PBG); standards were prepared using the same reagent concentrations as test samples. Plates were incubated in the dark at room temperature on an orbital plate shaker for $15 \mathrm{~min}$, after which the PBG concentration was determined by reading the absorbance at $540 \mathrm{~nm}$ with an automated 96-well plate scanner (Bio-Rad Laboratories Model 3550, Hercules, CA, USA). Enzyme activity in each well was computed as nmol PBG/ $\mu$ l blood/h using the sample absorbance reading and the parameters (slope and $y$ intercept) from the regression of the PBG standard curve and was reported as the arithmetic mean of the three observations representing each sample. Enzyme activity also was standardized to $\mathrm{Hb}$ concentration (as determined in the field by HemoCue) and reported as nmol PBG/mg Hb/h.

\section{Species composition, fish size, and age}

Carp $(n=23)$ were obtained from all six Oklahoma sites, the BR $(n=2)$, and LB $(n=16)$. Those analyzed for metals and biomarkers ( $n=5$ from LB) were of relatively uniform size and age; station means were 468 to $560 \mathrm{~mm}, 1,364$ to $2,225 \mathrm{~g}$, and two to 3.3 years old (data not shown). The LB carp used in the later parts of the temperature study were smaller and younger than most; however, they averaged 425 $\mathrm{mm}, 862 \mathrm{~g}$, and 1.8 years old.

Channel catfish $(n=20)$ also were obtained from all six Oklahoma sites and from reference sites $(n=15)$. Catfish were not aged. Overall, channel catfish averaged $400 \mathrm{~mm}$ and 581 $\mathrm{g}$, and the sizes of the reference fish bracketed the range represented by the fish from Oklahoma. Those from Oklahoma were of relatively uniform size except for those from site 1 , which generally were smaller than most (mean $=372 \mathrm{~mm}$, $371 \mathrm{~g}$ ). The commercially obtained channel catfish (site $8, n$ $=12$ ) were slightly smaller (mean $=327 \mathrm{~mm}, 230 \mathrm{~g}$ ) than those from site 1 , whereas those from our laboratory (site 7 , $n=3$ ) were larger (mean $=434 \mathrm{~mm}, 1,033 \mathrm{~g}$ ) as were those from the other Oklahoma sites. Flathead catfish $(n=4)$ were obtained only at Oklahoma sites 1 and 2 (data not shown), and no reference fish were available for analysis. The fish from site $1(n=2)$ were larger $(605-651 \mathrm{~mm}, 2,550-3,900 \mathrm{~g})$ than those from site $2(470-525 \mathrm{~mm}, 1,115-1,450 \mathrm{~g})$.

Largemouth bass $(n=8)$ were obtained from Oklahoma sites 1,5 , and 6 and from the BR $(n=1)$. Reference largemouth bass $(n=12)$ from our laboratory also were analyzed. Those from Oklahoma were all larger (243-456 mm, 152-1,600 g) than the specimen from the BR $(208 \mathrm{~mm}, 103 \mathrm{~g}$; data not shown). However, one large fish (from site 6) contributed greatly to the wide range. Largemouth bass from Oklahoma were one to three years old; the reference fish were two to three years old, and the fish from the BR was one year old. Overall, the largemouth bass averaged $335 \mathrm{~mm}, 559 \mathrm{~g}$, and 2.1 years old. Spotted bass $(n=7)$ were obtained from Oklahoma sites 2, 4, and 5 and from the BR $(n=2)$. They were 213 to $424 \mathrm{~mm}$ long, weighed 117 to $1,137 \mathrm{~g}$, and were one to three years old. Like the largemouth bass, one large fish (from site 1) contributed greatly to the wide range. In contrast, the one spotted bass obtained from site 5 was smaller than all others $(213 \mathrm{~mm}, 117 \mathrm{~g})$. Spotted bass from the BR were similar in size (245-294 mm, 217-403 g) and age (1-3 years old) to most from Oklahoma. Overall, the spotted bass included in the study (mean $=289 \mathrm{~mm}$ TL, $394 \mathrm{~g}$ ) were slightly smaller than the largemouth bass, as is typical of these species. No reference spotted bass were available for analysis.

Crappie $(n=12)$ were obtained from Oklahoma sites 3 through 6. They were 216 to $352 \mathrm{~mm}$, weighed 117 to $739 \mathrm{~g}$, and were one to three years old (data not shown). Overall, they averaged $284 \mathrm{~mm}, 353 \mathrm{~g}$, and 1.8 years old. The crappie from site $6(n=3)$ were larger $(315-352 \mathrm{~mm}, 451-739 \mathrm{~g})$ than those from the other sites (216-315 mm, 117-388 g). None were obtained from the BR or from any of the reference sites.

\section{Data management and statistical analysis}

Elemental concentrations were analyzed statistically as both dry weight and wet weight concentrations. For each variable, species-station arithmetic means and standard errors were computed and tabulated, as were summary statistics by species. All data representing elemental concentrations and ALA-D activity were $\log _{10}$-transformed before statistical analysis. A value of $50 \%$ LOD was substituted for censored values (i.e., those $<$ LOD) for all computations. A preliminary statistical analysis was conducted using analysis of covariance to determine the influence of various factors on metal concentrations and biomarkers. For these analyses, fish species, gender, collection site, and the interactions of these variables were considered fixed effects, and total length, fish weight, and age were considered continuous variables [26]. The preliminary analysis of covariance indicated that many variables differed among species and sites and that some interactions of species with other factors were significant; however, few other factors were significant (Table 2). All further statistical analyses, therefore, were conducted separately for each species. Oneway analysis of variance was used to test for differences among sites and groups of sites. In these analyses, site was considered a fixed effect, differences among individual sites were tested with Fisher's protected LSD, and differences among groups of sites were tested as planned nonorthogonal contrasts using single degree-of-freedom $F$ tests. Relations between and among groups of variables (transformed as described previously) were examined through the use of Pearson correlation coefficients, linear (least-squares) regression, and stepwise multiple linear regression. In the latter, the forward selection method was used and variables were allowed into the model only if they significantly $(p<0.05)$ reduced the unexplained sum of squares after accounting for all other factors already included in the model (i.e., the type-II sums of squares were used) [26]. Closely related species (Ictaluridae [catfish]; $\mathrm{Mi}$ cropterus spp.) were combined for these analyses. Molar concentrations of $\mathrm{Hb}$ and blood $\mathrm{Fe}$ (i.e., [ $\mathrm{Hb}]$ and $[\mathrm{Fe}]$ ) were computed on the basis of the approximate molecular weight of carp $\mathrm{Hb}(65.88 \mathrm{kDa})$ [27] and the atomic weight of $\mathrm{Fe}$ (55.85) and analyzed using simple linear regression and geometric mean (functional) regression [28]. Release 8.2 of the Statistical Analysis System [26] was used for all statistical analyses. 


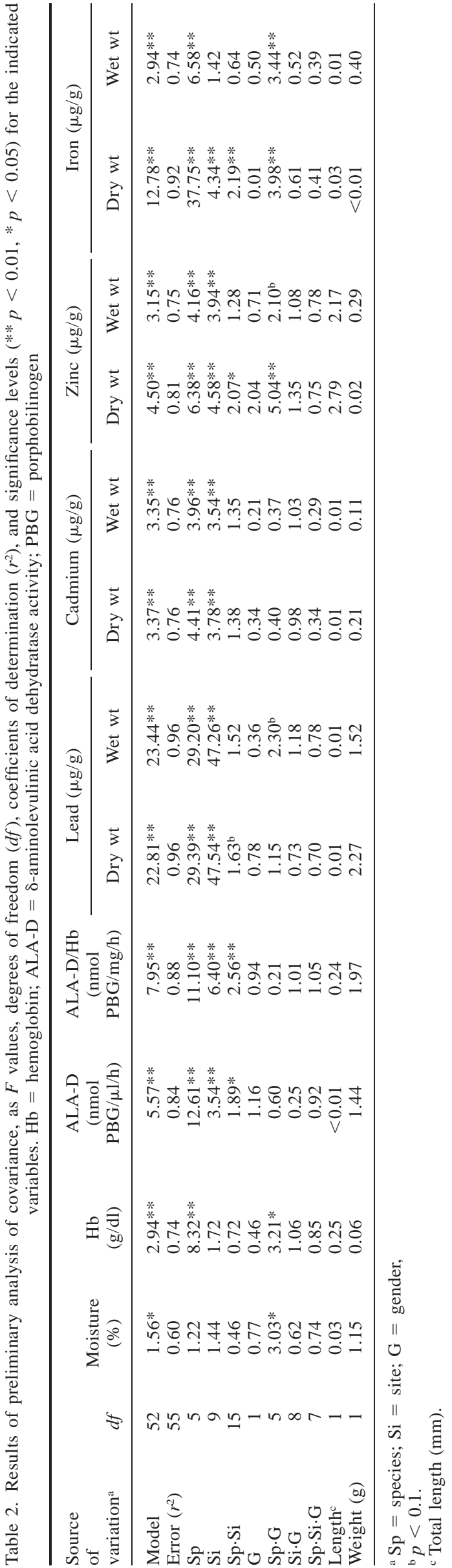

\section{RESULTS}

\section{Hemoglobin and ALA-D activity}

Hemoglobin. Overall, $\mathrm{Hb}$ concentrations differed significantly among species, but not among sites or between genders (Table 2). However, significant species $\times$ gender interaction indicated differences between genders in at least one species, but neither length nor weight were significant factors (Table 2 ). Concentrations of $\mathrm{Hb}$ were greater in carp than in all other species (Table 3). Concentrations in largemouth bass averaged slightly lower than in spotted bass, as did those in flathead catfish relative to channel catfish (Table 3). Concentrations of $\mathrm{Hb}$ did not differ significantly among locations in any of the species investigated (Table 3 ). Because the $\mathrm{Hb}$ concentrations were uniform across stations, within-species differences in $\mathrm{Hb}$ adjusted ALA-D activity (ALA-D/Hb) are not confounded by differing $\mathrm{Hb}$ concentrations.

ALA-D activity. The analysis of variance results for ALA-D and ALA-D/Hb were nearly identical; differences among sites and species were significant for both variables as were species $X$ site interactions (Table 2 ). The latter indicate that differences among sites were not consistent across the species investigated. Neither length nor weight significantly affected either variable (Table 2).

In general, ALA-D activity was greatest in bass and lowest in catfish, but it varied considerably within species and locations (Table 3). Unadjusted ALA-D activity differed significantly among locations in channel catfish, largemouth bass, and spotted bass, but not in carp or crappie (Table 3). Amonglocation differences were more evident for $\mathrm{Hb}$-adjusted than for unadjusted ALA-D; ALA-D/Hb differences were significant in all species except spotted bass, in which they also approached significance ( $p=0.10$; Table 3). Overall, ALA$\mathrm{D} / \mathrm{Hb}$ ranged from $0.43 \mathrm{nmol} / \mathrm{mg} \mathrm{Hb} / \mathrm{h}$ in a carp from site 6 (NR-TC) to $10.24 \mathrm{nmol} / \mathrm{mg} \mathrm{Hb} / \mathrm{h}$ in a reference largemouth bass.

In carp, ALA-D/Hb was greatest, on average, in fish from sites 3 (NR-reference), 4 (SR), and 10 (LB) and lowest in those from sites 2 (SR), 6 (NR-TC), and 9 (BR; Table 3). In channel catfish, ALA-D/Hb was greatest in the commercially obtained reference fish and at site 6 (NR-TC) and lowest at sites 1 and 2 (both SR; Table 3). Consequently, ALA-D activity was significantly lower overall in SR channel catfish than in those from the NR and reference fish, but ALA-D/Hb in channel catfish from the NR did not differ significantly from reference fish (Table 3).

Enzyme activity was significantly lower in both largemouth and spotted bass from the BR than in those from any of the Oklahoma sites, which did not differ from each other in either species (Table 3). Activity (as ALA-D/Hb) also was significantly greater in reference largemouth bass than in those from Oklahoma (Table 3), but no reference spotted bass were available for comparison. Activity in crappie was lowest at site 5 (NR) and greatest at site 3 (NR-reference), with the other two sites (2 and 4, both SR) intermediate (Table 3); however, the range of $\mathrm{ALA}-\mathrm{D} / \mathrm{Hb}$ in crappie was narrow relative to other species analyzed because neither reference nor positive control fish were obtained for comparison.

\section{Moisture content and metals}

Moisture. The moisture content of fish blood was consistent across the range of species and locations sampled; differences among stations and species were not significant $(p>0.05)$, 
Table 3. Hemoglobin $(\mathrm{Hb})$ concentrations $(\mathrm{g} / \mathrm{dl})$, Hb-adjusted $\delta$-aminolevulinic acid dehydratase (ALA-D) activity (nmol porphobilinogen [PBG]/ $\mathrm{mg} \mathrm{Hb} / \mathrm{h}$ ), unadjusted ALA-D activity (nmol PBG/ $\mu \mathrm{l} / \mathrm{h}$ ), and moisture content (\%) in the blood of six species of fish from the indicated sites $($ Ref $=$ reference; $\mathrm{SR}=$ Spring River; $\mathrm{NR}=$ Neosho River; $\mathrm{TC}=$ Tar Creek; BR $=$ Big River; LB $=$ Long Branch Lake $[$ all USA]). Shown are arithmetic station and river means (unweighted) and standard errors (SE), by species and site; and results of one-way analysis of variance (ANOVA) as $F$ values (** $p \leq 0.01 ; * 0.01<p \leq 0.05$; not significant [NS] $p>0.05$ ), coefficients of determination $\left(r^{2}\right)$, and degrees of freedom $(d f)$. Within taxa, means followed by the same letter are not significantly different $(p>0.05)$

\begin{tabular}{|c|c|c|c|c|c|}
\hline \multirow{2}{*}{$\begin{array}{l}\text { Species, site } \\
\text { and river }\end{array}$} & \multirow[b]{2}{*}{$n / d f$} & $\mathrm{Hb}$ & ALA-D/Hb & ALA-D & Moisture \\
\hline & & Mean $\pm \mathrm{SE}$ & Mean $\pm \mathrm{SE}$ & Mean $\pm \mathrm{SE}$ & Mean $\pm \mathrm{SE}$ \\
\hline Common carp & 30 & $9.2 \pm 0.29$ & $1.70 \pm 0.12$ & $1.53 \pm 0.10$ & $85.2 \pm 0.3$ \\
\hline 1 (SR) & 4 & $9.6 \pm 0.39 \mathrm{a}$ & $1.55 \pm 0.09 \mathrm{abc}$ & $1.50 \pm 0.15 \mathrm{a}$ & $85.0 \pm 1.0 \mathrm{a}$ \\
\hline 2 (SR) & 4 & $8.8 \pm 0.66 \mathrm{a}$ & $1.35 \pm 0.24 \mathrm{bc}$ & $1.19 \pm 0.23 \mathrm{a}$ & $85.8 \pm 0.7 \mathrm{a}$ \\
\hline $4(\mathrm{SR})$ & 3 & $9.3 \pm 1.25 \mathrm{a}$ & $2.22 \pm 0.39 \mathrm{ab}$ & $1.99 \pm 0.29 \mathrm{a}$ & $85.1 \pm 1.2 \mathrm{a}$ \\
\hline All SR & $3^{\mathrm{b}}$ & $9.2 \mathrm{~A}$ & $1.71 \mathrm{AB}$ & $1.56 \mathrm{~A}$ & $85.3 \mathrm{~A}$ \\
\hline $3(\mathrm{NR})$ & 4 & $8.4 \pm 0.97 \mathrm{a}$ & $2.55 \pm 0.07 \mathrm{a}$ & $2.14 \pm 0.26 \mathrm{a}$ & $86.2 \pm 0.8 \mathrm{a}$ \\
\hline $5(\mathrm{NR})$ & 3 & $11.1 \pm 0.61 \mathrm{a}$ & $0.92 \pm 0.18 \mathrm{c}$ & $1.04 \pm 0.26 \mathrm{a}$ & $83.2 \pm 0.5 \mathrm{a}$ \\
\hline 6 (NR-TC) & 5 & $10.0 \pm 0.58 \mathrm{a}$ & $1.28 \pm 0.30 \mathrm{c}$ & $1.29 \pm 0.33 \mathrm{a}$ & $85.0 \pm 0.6 \mathrm{a}$ \\
\hline All NR & $3^{\mathrm{b}}$ & $9.8 \mathrm{~A}$ & $1.58 \mathrm{~A}$ & $1.49 \mathrm{~A}$ & $84.9 \mathrm{~A}$ \\
\hline $9(\mathrm{BR})$ & 2 & $9.6 \pm 1.00 \mathrm{aA}$ & $1.34 \pm 0.05 \mathrm{abAB}$ & $1.29 \pm 0.18 \mathrm{aA}$ & $84.6 \pm 0.6 \mathrm{aA}$ \\
\hline 10 (LB) & $5^{c}$ & $7.9 \pm 0.57 \mathrm{aA}$ & $2.17 \pm 0.14 \mathrm{abB}$ & $1.68 \pm 0.07 \mathrm{aA}$ & $85.6 \pm 0.5 \mathrm{aA}$ \\
\hline ANOVA & 29 & - & - & - & - \\
\hline$F$ & 7 & $1.85 \mathrm{NS}$ & $4.06 * *$ & $2.00 \mathrm{NS}$ & $1.41 \mathrm{NS}$ \\
\hline$r^{2}$ & 22 & 0.37 & 0.56 & 0.39 & 0.31 \\
\hline Channel catfish & 35 & $6.9 \pm 0.21$ & $1.44 \pm 0.09$ & $0.97 \pm 0.05$ & $86.3 \pm 0.3$ \\
\hline $1(\mathrm{SR})$ & 5 & $7.0 \pm 0.50 \mathrm{a}$ & $0.78 \pm 0.09 \mathrm{a}$ & $0.55 \pm 0.08 \mathrm{bc}$ & $87.4 \pm 1.1 \mathrm{a}$ \\
\hline 2 (SR) & 1 & $8.5 \mathrm{a}$ & $0.58 \mathrm{a}$ & $0.49 \mathrm{c}$ & $86.0 \mathrm{a}$ \\
\hline $4(\mathrm{SR})$ & 5 & $6.4 \pm 0.86 \mathrm{a}$ & $1.48 \pm 0.36 \mathrm{~b}$ & $0.90 \pm 0.17 \mathrm{ab}$ & $87.2 \pm 1.1 \mathrm{a}$ \\
\hline All SR & $3^{\mathrm{b}}$ & $7.3 \mathrm{~A}$ & $0.95 \mathrm{~A}$ & $0.65 \mathrm{~A}$ & $85.9 \mathrm{~A}$ \\
\hline $3(\mathrm{NR})$ & 4 & $7.5 \pm 1.02 \mathrm{a}$ & $1.29 \pm 0.18 b$ & $0.96 \pm 0.16 \mathrm{ab}$ & $85.7 \pm 1.1 \mathrm{a}$ \\
\hline $5(\mathrm{NR})$ & 2 & $7.2 \pm 0.40 \mathrm{a}$ & $1.49 \pm 0.12 \mathrm{~b}$ & $1.07 \pm 0.03 \mathrm{a}$ & $86.2 \pm 0.1 \mathrm{a}$ \\
\hline 6 (NR-TC) & 3 & $7.5 \pm 0.84 \mathrm{a}$ & $1.74 \pm 0.28 \mathrm{~b}$ & $1.27 \pm 0.17 \mathrm{a}$ & $86.2 \pm 0.9 \mathrm{a}$ \\
\hline All NR & $3^{\mathrm{b}}$ & $7.4 \mathrm{~A}$ & $1.51 \mathrm{~B}$ & $1.10 \mathrm{~B}$ & $86.0 \mathrm{~A}$ \\
\hline 7 (Ref) & 3 & $6.7 \pm 0.35 \mathrm{a}$ & $1.97 \pm 0.28 \mathrm{~b}$ & $1.30 \pm 0.13 \mathrm{a}$ & $85.6 \pm 0.6 \mathrm{a}$ \\
\hline 8 (Ref) & 12 & $6.6 \pm 0.21 \mathrm{a}$ & $1.60 \pm 0.08 b$ & $1.04 \pm 0.05 \mathrm{a}$ & $86.0 \pm 0.3 \mathrm{a}$ \\
\hline All ref & $2^{\mathrm{b}}$ & $6.6 \mathrm{~A}$ & $1.79 \mathrm{~B}$ & $1.17 \mathrm{~B}$ & $85.8 \mathrm{~A}$ \\
\hline ANOVA & 34 & - & - & - & - \\
\hline$F$ & 7 & $0.74 \mathrm{NS}$ & $5.34 * * *$ & $4.30 * *$ & $0.73 \mathrm{NS}$ \\
\hline$r^{2}$ & 27 & 0.16 & 0.58 & 0.53 & 0.16 \\
\hline Flathead catfish $^{\mathrm{d}}$ & 4 & $5.9 \pm 1.21$ & $1.62 \pm 0.32$ & $0.86 \pm 0.08$ & $85.9 \pm 0.4$ \\
\hline $1(\mathrm{SR})$ & 2 & $5.9 \pm 2.05$ & $1.84 \pm 0.70$ & $0.93 \pm 0.03$ & $85.9 \pm 0.3$ \\
\hline 2 (SR) & 2 & $6.0 \pm 2.15$ & $1.39 \pm 0.23$ & $0.78 \pm 0.16$ & $85.9 \pm 0.09$ \\
\hline Largemouth bass & 21 & $6.5 \pm 0.29$ & $4.61 \pm 0.37$ & $2.92 \pm 0.19$ & $86.0 \pm 0.4$ \\
\hline 1 (SR) & 2 & $6.7 \pm 0.45 \mathrm{a}$ & $4.49 \pm 1.17 \mathrm{abA}$ & $2.93 \pm 0.58 \mathrm{aA}$ & $85.3 \pm 1.3 \mathrm{a}$ \\
\hline $5(\mathrm{NR})$ & 2 & $8.0 \pm 0.55 \mathrm{a}$ & $3.13 \pm 0.05 \mathrm{a}$ & $2.49 \pm 0.21 \mathrm{a}$ & $84.5 \pm 1.1 \mathrm{a}$ \\
\hline 6 (NR-TC) & 4 & $7.1 \pm 0.13 \mathrm{a}$ & $4.25 \pm 0.23 \mathrm{ab}$ & $3.02 \pm 0.19 \mathrm{a}$ & $85.2 \pm 0.1 \mathrm{a}$ \\
\hline All NR & $3^{\mathrm{b}}$ & $7.5 \mathrm{aA}$ & $3.69 \mathrm{~A}$ & $2.76 \mathrm{~A}$ & $84.8 \mathrm{aA}$ \\
\hline 7 (Ref) & 12 & $6.1 \pm 0.45 \mathrm{aA}$ & $5.25 \pm 0.51 \mathrm{bB}$ & $3.12 \pm 0.27 \mathrm{aA}$ & $86.6 \pm 0.6 \mathrm{aA}$ \\
\hline 9 (BR) & 1 & $6.6 \mathrm{aA}$ & $1.52 \mathrm{cC}$ & $1.00 \mathrm{bB}$ & $86.3 \mathrm{aA}$ \\
\hline ANOVA & 20 & - & - & - & - \\
\hline$F$ & 4 & $1.09 \mathrm{NS}$ & $6.10 * *$ & $3.19 *$ & $0.95 \mathrm{NS}$ \\
\hline$r^{2}$ & 16 & 0.21 & 0.60 & 0.44 & 0.19 \\
\hline Spotted bass & 9 & $8.3 \pm 0.46$ & $2.71 \pm 0.19$ & $2.26 \pm 0.22$ & $84.6 \pm 0.4$ \\
\hline $2(\mathrm{SR})$ & 3 & $9.1 \pm 0.42 \mathrm{a}$ & $2.80 \pm 0.33 \mathrm{ab}$ & $2.54 \pm 0.24 \mathrm{a}$ & $84.2 \pm 0.6 \mathrm{a}$ \\
\hline 4 (SR) & 3 & $8.0 \pm 1.11 \mathrm{a}$ & $2.88 \pm 0.13 \mathrm{a}$ & $2.30 \pm 0.31 \mathrm{a}$ & $84.9 \pm 1.0 \mathrm{a}$ \\
\hline All SR & $2^{\mathrm{b}}$ & $8.6 \mathrm{~A}$ & $2.84 \mathrm{~A}$ & $2.42 \mathrm{~A}$ & $84.6 \mathrm{~A}$ \\
\hline $5(\mathrm{NR})$ & 1 & $9.0 \mathrm{aA}$ & $3.42 \mathrm{aA}$ & $3.08 \mathrm{aA}$ & $84.2 \mathrm{aA}$ \\
\hline 9 (BR) & 2 & $7.2 \pm 0.75 \mathrm{aA}$ & $1.96 \pm 0.08 \mathrm{bB}$ & $1.40 \pm 0.09 \mathrm{bB}$ & $84.8 \pm 0.6 \mathrm{aA}$ \\
\hline ANOVA & 8 & - & - & - & - \\
\hline$F$ & 3 & $0.96 \mathrm{NS}$ & $4.13 * *$ & $5.60 * *$ & $0.19 \mathrm{NS}$ \\
\hline$r^{2}$ & 5 & 0.32 & 0.72 & 0.77 & 0.10 \\
\hline White crappie & 12 & $6.4 \pm 0.27$ & $2.40 \pm 0.16$ & $1.50 \pm 0.10$ & $84.9 \pm 0.5$ \\
\hline 4 (SR) & 3 & $5.9 \pm 0.77 \mathrm{aA}$ & $2.49 \pm 0.20 \mathrm{abA}$ & $1.50 \pm 0.29 \mathrm{abA}$ & $87.3 \pm 0.6 \mathrm{aA}$ \\
\hline 3 (NR) & 2 & $6.0 \pm 0.30 \mathrm{a}$ & $3.25 \pm 0.31 \mathrm{a}$ & $1.94 \pm 0.09 \mathrm{a}^{\mathrm{e}}$ & $84.9 \pm 0.6 \mathrm{~b}$ \\
\hline $5(\mathrm{NR})$ & 4 & $6.4 \pm 0.55 \mathrm{a}$ & $1.92 \pm 0.17 \mathrm{~b}$ & $1.21 \pm 0.09 \mathrm{~b}^{\mathrm{e}}$ & $83.2 \pm 0.6 b$ \\
\hline 6 (NR-TC) & 3 & $7.0 \pm 0.22 \mathrm{a}$ & $2.39 \pm 0.09 \mathrm{ab}$ & $1.67 \pm 0.08 \mathrm{ab}$ & $84.7 \pm 0.5 b$ \\
\hline All NR & $3^{b}$ & $6.5 \mathrm{~A}$ & $2.52 \mathrm{~A}$ & $1.61 \mathrm{~A}$ & $84.3 \mathrm{~B}$ \\
\hline ANOVA & 11 & - & - & - & - \\
\hline$F$ & 3 & $0.70 \mathrm{NS}$ & $6.35 * *$ & $2.95 \mathrm{NS}^{\mathrm{e}}$ & $9.32 * *$ \\
\hline$r^{2}$ & 8 & 0.21 & 0.72 & & 0.78 \\
\hline
\end{tabular}

${ }^{a}$ Lowercase letters for site means, uppercase for river means; ALA-D and ALA-D/Hb log-transformed for statistical analysis.

${ }^{\mathrm{b}}$ No. of means.

c One LB carp deleted due to low blood volume.

${ }^{d}$ Flathead catfish not analyzed statistically due to small $n$.

${ }^{\mathrm{e}} p=0.10$. 
and neither length nor weight were significant factors (Table 2). Blood moisture ranged from $81.9 \%$ in a crappie from site 5 to $93.1 \%$ in a reference largemouth bass (data not shown). Differences among locations were significant only in crappie (Table 3). These results indicate that most comparisons of wet weight metal concentrations are not confounded with moisture differences introduced in the conversion of dry weight to wet weight concentrations.

Lead. Blood-Pb concentrations (wet wt and dry wt) differed significantly among species and sites; trends were identical for both wet weight and dry weight concentrations, and no other factors were significant (Table 2). Lead was detected in all samples at concentrations ranging from $0.003 \mu \mathrm{g} / \mathrm{g}$ wet weight in a reference channel catfish to $3.69 \mu \mathrm{g} / \mathrm{g}$ in a carp from the BR (data not shown). At the Oklahoma sites, concentrations generally were greatest in carp and lowest in crappie (Table 4 ), but no reference of crappie was obtained for comparison. Blood- $\mathrm{Pb}$ concentrations in bass and catfish were intermediate relative to those in carp and crappie (Table 4).

Blood-Pb concentrations differed significantly among sites in all species (Table 4). Concentrations averaged $3.39 \mu \mathrm{g} / \mathrm{g}$ in carp from the BR and $0.04 \mu \mathrm{g} / \mathrm{g}$ in carp from LB; both differed significantly from all Oklahoma sites, which were intermediate (Table 4). Among the Oklahoma sites, $\mathrm{Pb}$ concentrations in carp from the SR (site means $0.20-0.36 \mu \mathrm{g} / \mathrm{g}$ ) were significantly greater than those from the NR (site means $0.10-0.19$ $\mu \mathrm{g} / \mathrm{g}$ ), and site 3 (NR-reference) concentrations were significantly lower than those from site 5 but not from other Oklahoma sites (Table 4).

Blood- $\mathrm{Pb}$ concentrations in channel catfish also were greater generally at SR than at NR sites, and concentrations at all Oklahoma sites exceeded those in both groups of reference fish (Table 4). Among the Oklahoma sites, concentrations in channel catfish were greatest at site $1(\mathrm{SR}$, mean $=0.16 \mu \mathrm{g}$ / g) and lowest at sites 3 (NR-reference) and $5(\mathrm{NR}$, means $=$ $0.04 \mu \mathrm{g} / \mathrm{g})$. Overall, $\mathrm{Pb}$ concentrations in channel catfish from the NR were significantly lower than in those from the SR (Table 4). Concentrations in flathead catfish from SR sites 1 and 2 were lower than in channel catfish from those sites but were not tested statistically (Table 4).

The blood $-\mathrm{Pb}$ concentration of the largemouth bass from the BR $(1.97 \mu \mathrm{g} / \mathrm{g})$ was more than 50 -fold greater than that of most Oklahoma largemouth bass and as much as 200-fold greater than reference fish (Table 4). Concentrations also were significantly greater in largemouth bass from Oklahoma than in reference fish, and those from sites 1 (SR) and 6 (NR-TC) exceeded those from site $5(\mathrm{NR})$; however, $\mathrm{Pb}$ concentrations in largemouth bass from the SR and NR did not differ significantly overall (Table 4).

In spotted bass and crappie, the blood- $\mathrm{Pb}$ trends at the Oklahoma sites were similar to those observed in largemouth bass, but no reference fish of either species were obtained, nor were crappie obtained from the BR (Table 4). Blood-Pb concentrations in spotted bass from the BR (mean $=1.24 \mu \mathrm{g} / \mathrm{g}$, $n=2$ ) were more than 10 -fold greater than in all spotted bass from Oklahoma, and also were significantly greater at site 2 (SR) than at site 4 (NR); however, as was true also for largemouth bass, the SR and NR did not differ significantly overall (Table 4). Blood-Pb concentrations in crappie spanned a relatively narrow range $(0.01-0.05 \mu \mathrm{g} / \mathrm{g})$ compared to the other taxa (Table 4), even among Oklahoma sites. Nevertheless, concentrations in crappie from site 4 (SR) were significantly great- er than all NR sites except site 6 (NR-TC) and the NR sites collectively (Table 4).

Cadmium. Blood-Cd concentrations (wet wt and dry wt) differed significantly among species and sites but no other factors were significant (Table 2). Concentrations generally were greatest in carp and lowest in the centrarchids, ranging from $<0.001 \mu \mathrm{g} / \mathrm{g}$ (wet wt) in most reference fish to 0.050 $\mu \mathrm{g} / \mathrm{g}$ in a carp from NR site 3 . Blood-Cd concentrations were $>$ LOD in only 48 of 111 samples (43\%), mostly in carp and catfish. Consequently, results of statistical tests are only approximate.

Blood-Cd concentrations in carp differed significantly among sites, but the differences were less evident than for blood $\mathrm{Pb}$ (Table 4). Concentrations were lowest in fish from LB and greatest in those from site 3 (NR-reference) and the BR. Overall, the SR and NR did not differ significantly (Table 4). Concentrations in channel catfish also differed significantly among sites; generally they were greatest in the SR, intermediate in the NR, and lowest in reference fish (Table 4). Blood-Cd concentrations in channel catfish from the SR and NR differed significantly from reference fish, but overall differences between the SR and NR were not significant (Table 4). Concentrations in flathead catfish from SR sites 1 and 2 exceeded those in channel catfish from these sites (Table 4) but were not tested statistically. Concentrations were universally low $(<0.001-0.003 \mu \mathrm{g} / \mathrm{g})$ in all three centrarchid species. Differences among sites were marginally significant $(0.05<$ $p<0.10)$ in largemouth bass but not in spotted bass or crappie (Table 4).

Zinc. Blood-Zn concentrations (wet wt and dry wt) differed significantly among species and sites (Table 2). In addition, species $\times$ gender interaction was significant for dry weight blood $\mathrm{Zn}$, indicating that concentrations differed between genders in at least one species; however, this term was not significant for the wet-weight values, and neither length nor weight were significant for either set of concentrations (Table 2). Concentrations ranged from $3.5 \mu \mathrm{g} / \mathrm{g}$ (wet wt) in a reference largemouth bass to $29.9 \mu \mathrm{g} / \mathrm{g}$ in a carp from site 3 (NRreference), and were $>$ LOD in all samples (data not shown), and generally were greatest in carp and catfish and lowest in the centrarchids (Table 4).

Compared to $\mathrm{Pb}$ and $\mathrm{Cd}$, blood-Zn concentrations in carp were relatively uniform across the range of stations sampled. Site means ranged from $7.5 \mu \mathrm{g} / \mathrm{g}$ (wet wt) at LB to $14.9 \mu \mathrm{g} /$ $\mathrm{g}$ at site 3 (NR-reference), but differences among sites were not statistically significant (Table 4). In contrast, blood-Zn concentrations in channel catfish differed significantly among sites; concentrations were significantly greater at sites 4 (SR) and 6 (NR-TC) than at all other Oklahoma sites (Table 4). Concentrations in fish from the SR were significantly lower overall than those from the NR and the reference sites, but the NR sites did not differ overall from the reference sites (Table 4). Concentrations in flathead catfish from sites 1 and 2 exceeded those in channel catfish from these sites (Table 4) but were not tested statistically. Blood-Zn concentrations in largemouth bass also differed significantly among sites (Table 4). Concentrations were significantly greater in largemouth bass from all Oklahoma sites than in those from either the BR (one fish) or the reference site, but the Oklahoma sites did not differ significantly among themselves (Table 4). Differences in spotted bass and crappie were not statistically significant (Table 4), but no reference fish of either species were analyzed nor were any crappie from the BR. 
Table 4. Concentrations of zinc, cadmium, lead, and iron (all $\mu \mathrm{g} / \mathrm{g}$ wet wt) in the blood of six species of fish from the indicated sites $($ Ref $=$ reference; SR $=$ Spring River; NR $=$ Neosho River; TC $=$ Tar Creek; BR = Big River; LB = Long Branch Lake [all USA]). Shown are arithmetic station and river means (unweighted) and standard errors (SE), by species and site; and results of one-way analysis of variance (ANOVA) as $F$ values (** $p \leq 0.01 ; * 0.01<p \leq 0.05$; not significant [NS] $p>0.05$ ), coefficients of determination $\left(r^{2}\right)$, and degrees of freedom $(d f)$. Within taxa, means followed by the same letter ${ }^{\mathrm{a}}$ are not significantly different $(p>0.05)$

\begin{tabular}{|c|c|c|c|c|c|}
\hline \multirow{2}{*}{$\begin{array}{l}\text { Species, site } \\
\text { and river }\end{array}$} & \multirow[b]{2}{*}{$n / d f$} & Zinc & Cadmium & Lead & Iron \\
\hline & & Mean $\pm \mathrm{SE}$ & Mean $\pm \mathrm{SE}$ & Mean $\pm \mathrm{SE}$ & Mean $\pm \mathrm{SE}$ \\
\hline Common carp & 30 & $10.5 \pm 0.9$ & $0.008 \pm 0.002$ & $0.38 \pm 0.18$ & $319.5 \pm 8.7$ \\
\hline $1(\mathrm{SR})$ & 4 & $12.9 \pm 1.5 \mathrm{a}$ & $0.013 \pm 0.008 \mathrm{abcd}$ & $0.20 \pm 0.04 \mathrm{bc}$ & $343.5 \pm 23.2 \mathrm{a}$ \\
\hline $2(\mathrm{SR})$ & 4 & $8.7 \pm 0.7 \mathrm{a}$ & $0.008 \pm 0.001 \mathrm{abc}$ & $0.26 \pm 0.05 \mathrm{bc}$ & $308.6 \pm 24.4 \mathrm{a}$ \\
\hline 4 (SR) & 3 & $11.5 \pm 1.5 \mathrm{a}$ & $0.003 \pm 0.002 \mathrm{abcd}$ & $0.36 \pm 0.15 b$ & $309.6 \pm 36.7 \mathrm{a}$ \\
\hline All SR & $3^{\mathrm{b}}$ & $11.0 \mathrm{~A}$ & $0.007 \mathrm{~A}$ & $0.27 \mathrm{~A}$ & $320.6 \mathrm{~A}$ \\
\hline $3(\mathrm{NR})$ & 4 & $14.9 \pm 5.1 \mathrm{a}$ & $0.018 \pm 0.011 \mathrm{ab}$ & $0.10 \pm 0.01 \mathrm{c}$ & $289.7 \pm 32.2 \mathrm{a}$ \\
\hline $5(\mathrm{NR})$ & 3 & $9.9 \pm 0.2 \mathrm{a}$ & $0.003 \pm 0.002 \mathrm{~cd}$ & $0.18 \pm 0.06 \mathrm{bc}$ & $371.8 \pm 17.5 \mathrm{a}$ \\
\hline 6 (NR-TC) & 5 & $9.5 \pm 2.6 \mathrm{a}$ & $0.004 \pm 0.002 \mathrm{bcd}$ & $0.19 \pm 0.07 \mathrm{bc}$ & $329.3 \pm 17.5 \mathrm{a}$ \\
\hline All NR & $3^{\mathrm{b}}$ & $11.4 \mathrm{~A}$ & $0.008 \mathrm{AB}$ & $0.15 \mathrm{~B}$ & $330.3 \mathrm{~A}$ \\
\hline 9 (BR) & 2 & $9.3 \pm 2.3 \mathrm{aA}$ & $0.020 \pm 0.013 \mathrm{aB}$ & $3.39 \pm 0.30 \mathrm{aC}$ & $305.0 \pm 13.4 \mathrm{aA}$ \\
\hline $10(\mathrm{LB})$ & $5^{\mathrm{c}}$ & $7.5 \pm 0.6 \mathrm{aA}$ & $<0.001 \pm<0.011 \mathrm{dC}$ & $0.04 \pm 0.01 \mathrm{dD}$ & $303.2 \pm 17.2 \mathrm{aA}$ \\
\hline ANOVA & 29 & - & - & - & - \\
\hline$F$ & 7 & $1.35 \mathrm{NS}$ & $2.91 *$ & $16.27 * *$ & $1.09 \mathrm{NS}$ \\
\hline$r^{2}$ & 22 & 0.30 & 0.48 & 0.84 & 0.26 \\
\hline Channel catfish & 35 & $14.8 \pm 0.5$ & $0.02 \pm<0.001$ & $0.06 \pm 0.01$ & $238.9 \quad 7.3$ \\
\hline $1(\mathrm{SR})$ & 5 & $11.5 \pm 1.1 \mathrm{ac}$ & $0.003 \pm 0.001 \mathrm{a}$ & $0.16 \pm 0.01 \mathrm{a}$ & $240.0 \pm 24.2 \mathrm{a}$ \\
\hline $2(\mathrm{SR})$ & 1 & $9.4 \mathrm{ac}$ & $0.003 \mathrm{a}$ & $0.09 \mathrm{a}$ & $285.6 \mathrm{a}$ \\
\hline 4 (SR) & 5 & $15.3 \pm 0.9 \mathrm{~b}$ & $0.003 \pm 0.002 \mathrm{ab}$ & $0.08 \pm 0.02 \mathrm{~b}$ & $218.5 \pm 25.3 \mathrm{a}$ \\
\hline All SR & $3^{\mathrm{b}}$ & $12.1 \mathrm{~A}$ & $0.003 \mathrm{~A}$ & $0.11 \mathrm{~A}$ & $248.0 \mathrm{~A}$ \\
\hline $3(\mathrm{NR})$ & 4 & $12.2 \pm 0.2 \mathrm{ac}$ & $0.003 \pm 0.001 \mathrm{a}$ & $0.04 \pm 0.01 \mathrm{bc}$ & $286.6 \pm 32.7 \mathrm{a}$ \\
\hline $5(\mathrm{NR})$ & 2 & $14.8 \pm 2.0 \mathrm{bc}$ & $<0.001 \pm<0.001 \mathrm{bc}$ & $0.04 \pm 0.01 \mathrm{bc}$ & $240.8 \pm 3.8 \mathrm{a}$ \\
\hline 6 (NR-TC) & 3 & $15.3 \pm 1.8 \mathrm{~b}$ & $0.003 \pm 0.002 \mathrm{a}$ & $0.08 \pm 0.02 \mathrm{~b}$ & $246.5 \pm 25.0 \mathrm{a}$ \\
\hline All NR & $3^{\mathrm{b}}$ & $14.1 \mathrm{~B}$ & $0.002 \mathrm{~A}$ & $0.05 \mathrm{~B}$ & $258.0 \mathrm{~A}$ \\
\hline 7 (Ref) & 3 & $15.2 \pm 0.7 \mathrm{bc}$ & $<0.001 \pm<0.001 \mathrm{c}$ & $<0.01 \pm<0.01 \mathrm{~d}$ & $209.0 \pm 6.4 \mathrm{a}$ \\
\hline 8 (Ref) & 12 & $17.1 \pm 0.6 \mathrm{~b}$ & $<0.001 \pm<0.001 \mathrm{c}$ & $0.02 \pm<0.01 \mathrm{c}$ & $232.3 \pm 5.9 \mathrm{a}$ \\
\hline All Ref & $2^{\mathrm{b}}$ & $16.2 \mathrm{~B}^{\mathrm{b}}$ & $<0.001 \mathrm{~B}$ & $0.01 \mathrm{C}$ & $220.6 \mathrm{~A}$ \\
\hline ANOVA & 34 & - & - & - & - \\
\hline$F$ & 7 & $5.95 * *$ & $5.76 * *$ & $32.81 * *$ & $1.28 \mathrm{NS}$ \\
\hline$r^{2}$ & 27 & 0.61 & 0.59 & 0.89 & 0.25 \\
\hline Flathead catfish ${ }^{d}$ & 4 & $14.5 \pm 0.6$ & $0.005 \pm 0.002$ & $0.04 \pm 0.01$ & $228.9 \pm 18.9$ \\
\hline $1(\mathrm{SR})$ & 2 & $14.6 \pm 0.8$ & $0.004 \pm 0.001$ & $0.04 \pm<0.01$ & $236.5 \pm 11.9$ \\
\hline $2(\mathrm{SR})$ & 2 & $14.4 \pm 0.8$ & $0.006 \pm 0.004$ & $0.03 \pm 0.01$ & $221.2 \pm 43.0$ \\
\hline Largemouth bass & 21 & $8.9 \pm 0.6$ & $0.001 \pm<0.001$ & $0.11 \pm 0.09$ & $226.3 \pm 6.4$ \\
\hline $1(\mathrm{SR})$ & 2 & $10.9 \pm 1.9 \mathrm{abA}$ & $0.001 \pm<0.001 \mathrm{aA}$ & $0.04 \pm 0.01 \mathrm{aA}$ & $231.7 \pm 14.7 \mathrm{aA}$ \\
\hline $5(\mathrm{NR})$ & 2 & $10.3 \pm 1.1 \mathrm{abc}$ & $0.001 \pm<0.001 \mathrm{ab}$ & $0.02 \pm<0.01 \mathrm{~b}$ & $241.5 \pm 12.4 \mathrm{a}$ \\
\hline 6 (NR-TC) & 4 & $12.3 \pm 1.0 \mathrm{ab}$ & $<0.001 \pm<0.001 \mathrm{ab}$ & $0.04 \pm<0.01 \mathrm{a}$ & $237.6 \pm 4.2 \mathrm{a}$ \\
\hline All NR & $3^{\mathrm{b}}$ & $11.3 \mathrm{~A}$ & $0.001 \mathrm{AB}$ & $0.03 \mathrm{~A}$ & $239.6 \mathrm{~A}$ \\
\hline 7 (Ref) & 12 & $7.3 \pm 0.4 \mathrm{cB}$ & $<0.001 \pm<0.001 \mathrm{abA}$ & $0.01 \pm<0.01 \mathrm{bB}$ & $222.2 \pm 10.1 \mathrm{aA}$ \\
\hline 9 (BR) & 1 & $9.2 \mathrm{bcB}$ & $<0.001 \mathrm{bB}$ & $1.97 \mathrm{cC}$ & $189.1 \mathrm{aA}$ \\
\hline ANOVA & 20 & - & - & - & - \\
\hline$F$ & 4 & $4.92 * *$ & $2.62 * \mathrm{e}$ & $39.68 * *$ & $0.51 \mathrm{NS}$ \\
\hline$r^{2}$ & 16 & 0.55 & 0.40 & 0.91 & 0.42 \\
\hline Spotted bass & 9 & $12.2 \pm 0.5$ & $0.001 \pm<0.001$ & $0.33 \pm 0.17$ & $254.2 \pm 11.1$ \\
\hline $2(\mathrm{SR})$ & 3 & $11.9 \pm 0.1 \mathrm{a}$ & $0.001 \pm<0.001 \mathrm{a}$ & $0.09 \pm 0.01 \mathrm{a}$ & $276.4 \pm 16.3 \mathrm{a}$ \\
\hline 4 (SR) & 3 & $12.4 \pm 1.2 \mathrm{a}$ & $<0.001 \pm<0.001 \mathrm{a}$ & $0.06 \pm 0.01 \mathrm{ab}$ & $253.0 \pm 23.9 \mathrm{a}$ \\
\hline All SR & $2^{\mathrm{b}}$ & $12.2 \mathrm{~A}$ & $0.001 \mathrm{~A}$ & $0.07 \mathrm{~A}$ & $264.7 \mathrm{~A}$ \\
\hline $5(\mathrm{NR})$ & 1 & $13.2 \mathrm{aA}$ & $<0.001 \mathrm{aA}$ & $0.04 \mathrm{bA}$ & $256.0 \mathrm{aA}$ \\
\hline 9 (BR) & 2 & $12.0 \pm 1.7 \mathrm{aA}$ & $0.002 \pm 0.001 \mathrm{aA}$ & $1.24 \pm 0.14 \mathrm{cB}$ & $222.0 \pm 10.3 \mathrm{aA}$ \\
\hline ANOVA & 8 & - & - & - & - \\
\hline$F$ & 3 & $0.15 \mathrm{NS}$ & $1.70 \mathrm{NS}$ & $57.56 * *$ & $1.22 \mathrm{NS}$ \\
\hline$r^{2}$ & 5 & 0.08 & 0.50 & 0.97 & 0.42 \\
\hline White crappie & 12 & $9.6 \pm 0.4$ & $0.001 \pm<0.001$ & $0.03 \pm<0.01$ & $212.1 \pm 8.1$ \\
\hline $4(\mathrm{SR})$ & 3 & $8.3 \pm 1.0 \mathrm{aA}$ & $<0.001 \pm<0.001 \mathrm{aA}$ & $0.04 \pm<0.01 \mathrm{aA}$ & $184.4 \pm 18.2 \mathrm{aA}$ \\
\hline 3 (NR) & 2 & $10.5 \pm 0.8 \mathrm{a}$ & $<0.001 \pm 0.001 \mathrm{a}$ & $0.02 \pm 0.01 \mathrm{~b}$ & $206.8 \pm 6.8 \mathrm{a}$ \\
\hline $5(\mathrm{NR})$ & 4 & $9.6 \pm 0.4 \mathrm{a}$ & $<0.001 \pm<0.001 \mathrm{a}$ & $0.02 \pm<0.01 \mathrm{~b}$ & $217.7 \pm 11.1 \mathrm{a}$ \\
\hline 6 (NR-TC) & 3 & $10.2 \pm 1.1 \mathrm{a}$ & $<0.001 \pm<0.001 \mathrm{a}$ & $0.03 \pm 0.01 \mathrm{ab}$ & $235.9 \pm 13.0 \mathrm{a}$ \\
\hline All NR & $3^{\mathrm{b}}$ & $10.1 \mathrm{~A}$ & $0.001 \mathrm{~A}$ & $0.02 \mathrm{~B}$ & $220.1 \mathrm{~A}$ \\
\hline ANOVA & 11 & - & - & - & - \\
\hline$F$ & 3 & $1.25 \mathrm{NS}$ & $0.46 \mathrm{NS}$ & $6.48 *$ & $2.34 \mathrm{NS}$ \\
\hline$r^{2}$ & 8 & 0.32 & 0.15 & 0.71 & 0.47 \\
\hline
\end{tabular}

${ }^{\text {a }}$ Lowercase letters for site means, uppercase for river means; all variables log-transformed for statistical analysis.

${ }^{\mathrm{b}}$ No. of means.

${ }^{c}$ One LB carp with low blood volume deleted.

${ }^{\mathrm{d}}$ Flathead catfish not analyzed statistically due to small $n$.

${ }^{\mathrm{e}} p=0.06$. 


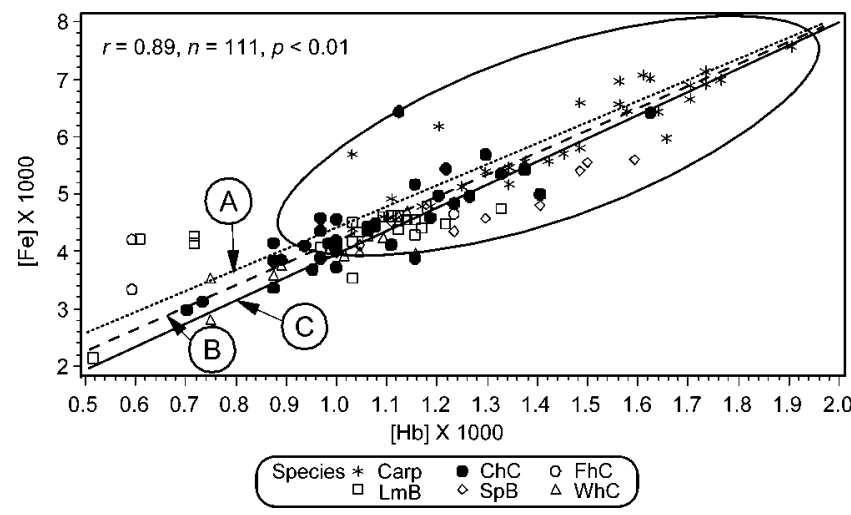

Fig. 2. Molar concentrations of $[\mathrm{Fe}]$ and hemoglobin $([\mathrm{Hb}])$ in the blood of fish of the indicated species. Also shown is the area of the graph representing all carp (ellipse) and lines representing the leastsquares (A) and functional (geometric mean) relation (B). Also shown (C) is the line representing $[\mathrm{Fe}]=4[\mathrm{Hb}]$, the expected relation based on the tetrameric structure of $\mathrm{Hb}$. See Table 5 for equations. Species: Carp $=$ common carp $; \mathrm{ChC}=$ channel catfish $; \mathrm{FhC}=$ flathead catfish; $\mathrm{LmB}=$ largemouth bass; $\mathrm{SpB}=$ spotted bass; $\mathrm{WhC}=$ white crappie.

Iron. Blood-Fe concentrations (wet wt and dry wt) differed significantly among species; however, only the dry-weight concentrations differed among sites, and neither length nor weight were significant factors (Table 2). Differences among sites were not consistent among species, as indicated by the significant species $\times$ site interaction (Table 2). Concentrations ranged from $114.5 \mu \mathrm{g} / \mathrm{g}$ (wet wt) in a reference largemouth bass to $404.1 \mu \mathrm{g} / \mathrm{g}$ in a carp from site 5 (NR) and were $>$ LOD in all samples (data not shown). Blood-Fe concentrations generally were greater in carp (all $\geq 305 \mu \mathrm{g} / \mathrm{g}$ ) than in all other species (typically 200-300 $\mu \mathrm{g} / \mathrm{g}$ ), but differences among sites were not significant in any species (Table 4 ).

\section{Relations between and among variables}

The molar concentrations of $\mathrm{Fe}$ and $\mathrm{Hb}$ were correlated highly in all taxa, both individually $(r=0.76-0.89, p<0.01)$ and collectively ( $r=0.89, p<0.01$; Fig. 2 ). Across all species investigated, the relation between $[\mathrm{Fe}]$ and $[\mathrm{Hb}]$ was welldescribed by least-squares and functional regressions, both of which were highly significant $(p<0.01)$ and explained $79 \%$ of the variability in [Fe] (Fig. 2, Table 5). In addition, the slopes of these regressions were near 4.0 and the intercepts near 0.0 , the expected values based on the tetrameric structure of $\mathrm{Hb}$ (Fig. 2, Table 5). Concentrations of $\mathrm{Hb}$ and $\mathrm{Fe}$ also were

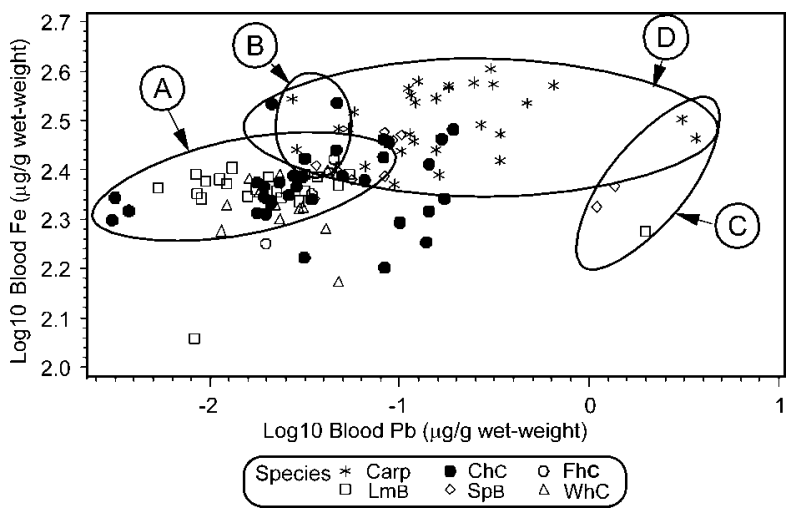

Fig. 3. Concentrations of $\mathrm{Fe}$ and $\mathrm{Pb}$ in blood of fish of the indicated species. Also shown are areas of the graph illustrating all laboratoryraised reference fish (A); all fish from Long Branch Lake (B) and the Big River, USA (C); and all carp (D). Species: Carp = common carp; $\mathrm{ChC}=$ channel catfish; $\mathrm{FhC}=$ flathead catfish; $\mathrm{LmB}=$ largemouth bass; $\mathrm{SpB}=$ spotted bass; $\mathrm{WhC}=$ white crappie.

positively correlated with those of $\mathrm{Zn}$ in bass $(r=0.60, p<$ $0.01)$ and (weakly) in crappie $(r=0.48, p=0.11)$. In contrast, neither blood $\mathrm{Fe}$ nor $\mathrm{Hb}$ were correlated with blood $\mathrm{Pb}$ in any taxa, and blood $\mathrm{Pb}$ was not elevated in fish with low $\mathrm{Hb}$ or Fe (Figs. 2 and 3).

Blood $\mathrm{Pb}$ and $\mathrm{ALA}-\mathrm{D} / \mathrm{Hb}$ were negatively correlated in catfish $(r=-0.66, p<0.01)$ and bass $(r=-0.82, p<0.01)$, but not in carp $(r=-0.26, p>0.05)$ or crappie $(r=0.11$, $p>0.05$; Fig. 4). However, the range of blood-Pb and ALA$\mathrm{D}$ values for crappie probably were not sufficient to document a statistical relationship (Fig. 4). In carp, points representing four fish (two each from sites 3 and 6) were conspicuously outside the general trend of the data (Fig. 4). Without these four points, the correlation improved $(r=-0.53, p<0.01)$. Nevertheless, it is important to note that there was no a priori reason to eliminate these fish (i.e., they appeared normal in all other respects).

Stepwise multiple regression of ALA-D activity against blood-metal concentrations (wet wt) and other variables yielded statistically significant improvements relative to the correlations between pairs of variables, but not in all taxa. In bass (largemouth and spotted combined), the data were well described by models that included negative terms for blood $\mathrm{Pb}$ after accounting for $\mathrm{Hb}$ differences between the species, either by analyzing $\mathrm{ALA}-\mathrm{D} / \mathrm{Hb}$ or by including $\mathrm{Hb}$ as an independent

Table 5. Statistically significant $(* * p<0.01 ; * p<0.05)$ regression models describing relations between wet-weight (ww) concentrations of hemoglobin $(\mathrm{Hb}), \mathrm{Fe}, \mathrm{Pb}, \mathrm{Zn}, \delta$-aminolevulinic acid dehydratase (ALA-D) activity, and Hb-adjusted ALA-D activity (ALA-D/Hb) in the blood of bass (largemouth and spotted), catfish (channel and flathead), carp, and all species combined. Shown for each model are intercepts and regression coefficients ( \pm standard errors), $F$ values and degrees of freedom $(d f)$, and coefficients of determination $\left(r^{2}\right)$

\begin{tabular}{|c|c|c|c|}
\hline Taxon & Model & $F(d f)$ & $r^{2}$ \\
\hline All species & $\begin{array}{l}{[\mathrm{Fe}]=0.0009( \pm 0.0002)+3.4280( \pm 0.1698)[\mathrm{Hb}]} \\
{[\mathrm{Fe}]=0.2965( \pm 0.0002)+3.8570( \pm 0.1698)[\mathrm{Hb}]}\end{array}$ & $\begin{array}{l}407.54(1,109)^{* *} \\
407.54(1,109)^{* *}\end{array}$ & $\begin{array}{l}0.79 \\
0.79\end{array}$ \\
\hline Bass $^{\mathrm{a}}$ & $\begin{aligned} \log _{10} \text { ALAD/Hb } & =0.258( \pm 0.045)-0.219( \pm 0.029) \log _{10} \mathrm{~Pb} \\
\log _{10} \text { ALA-D } & =-0.161( \pm 0.102)-0.198( \pm 0.028) \log _{10} \mathrm{~Pb}+0.040( \pm 0.12) \mathrm{Hb}\end{aligned}$ & $\begin{array}{l}58.51(1,27)^{* *} \\
26.55(2,27)^{* *}\end{array}$ & $\begin{array}{l}0.68 \\
0.66\end{array}$ \\
\hline Catfish ${ }^{\mathrm{b}}$ & $\begin{aligned} \log _{10} \text { ALA-D } / H b= & -1.206( \pm 0.229)-0.237( \pm 0.063) \log _{10} \mathrm{~Pb}+0.868( \pm 0.226) \log _{10} \mathrm{Zn}_{\mathrm{ww}} \\
\log _{10} \mathrm{ALA}-\mathrm{D}= & -3.435( \pm 0.605)-0.188( \pm 0.062) \log _{10} \mathrm{~Pb}+0.845( \pm 0.221) \log _{10} \mathrm{Zn} \\
& +0.903( \pm 0.227) \log _{10} \mathrm{Fe}\end{aligned}$ & $\begin{array}{l}30.20(2,33)^{* *} \\
19.25(3,32)^{* *}\end{array}$ & $\begin{array}{l}0.65 \\
0.64\end{array}$ \\
\hline Carp & $\begin{aligned} \log _{10} \text { ALA-D } / H b & =0.153( \pm 0.040)-0.131( \pm 0.043) \log _{10} \mathrm{~Pb} \\
\log _{10} \text { ALA-D } & =-0.155( \pm 0.159)-0.109( \pm 0.046) \log _{10} \mathrm{~Pb}+0.030( \pm 0.015) \mathrm{Hb}\end{aligned}$ & $\begin{array}{l}9.18(1,25)^{* *} \\
3.39(3,39)^{*}\end{array}$ & $\begin{array}{l}0.28 \\
0.23\end{array}$ \\
\hline
\end{tabular}

${ }^{\text {a }}$ Largemouth and smallmouth bass.

${ }^{\mathrm{b}}$ Channel and flathead catfish. 


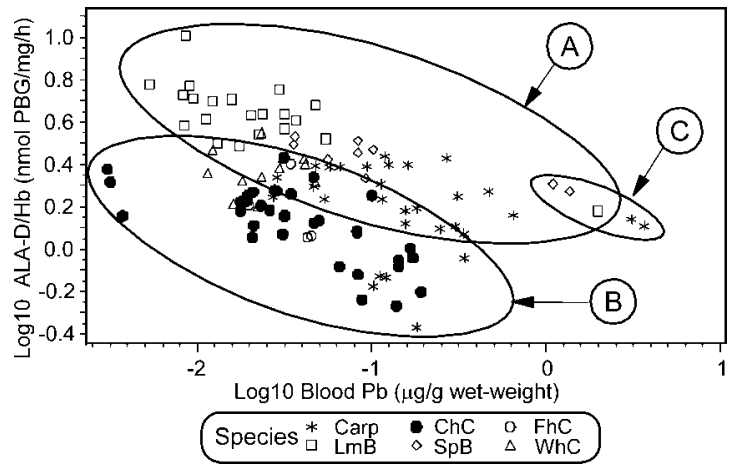

Fig. 4. Hemoglobin-adjusted $\delta$-aminolevulinic acid dehydratase activity versus blood-lead concentrations in fish of the indicated species. Also shown is the area of the graph representing (A) all bass ( $\mathrm{Mi}$ cropterus spp.), (B) all catfish (Ictaluridae), and (C) all fish from the Big River, USA. Species: Carp $=$ common carp; $\mathrm{ChC}=$ channel catfish; FhC = flathead catfish; $\mathrm{LmB}=$ largemouth bass; $\mathrm{SpB}=$ spotted bass; $\mathrm{WhC}=$ white crappie.

variable. These models were highly significant $(p<0.01)$ and accounted for 66 to $68 \%$ of the variation in ALA-D activity in bass (Fig. 4, Table 5). No other variables met the $p<0.05$ criterion for inclusion.

In catfish (channel and flathead combined), ALA-D activity also was well described by blood $\mathrm{Pb}$ after accounting for $\mathrm{Hb}$ differences and, in contrast to bass, blood Zn was statistically significant (Table 5). Models for both ALA-D and ALA-D/Hb were highly significant $(p<0.01)$ and accounted for 64 to $65 \%$ of the variation in ALA-D activity (Fig. 4, Table 5). No other variables met the $p<0.05$ criterion for inclusion. Blood Fe was selected in lieu of $\mathrm{Hb}$ in catfish; however, as noted previously, these variables were highly correlated (Fig. 2, Table 5).

In crappie, models that included terms for blood $\mathrm{Pb}$ and Zn were statistically significant $(p<0.05)$ and explained 52 to $61 \%$ of the variation in ALA-D activity (data not shown). The models for crappie differed from all others in that the coefficients for blood $\mathrm{Pb}$ were positive and those for $\mathrm{Zn}$ were negative, which is contrary to expectations. These results probably are an artifact of the narrow range spanned by blood- $\mathrm{Pb}$ concentrations and ALA-D activity in crappie, which were obtained only from Oklahoma sites 3 to 6 (Fig. 4).

No statistically significant models resulted for carp when all data $(n=30)$ and all variables were included. When the four fish identified previously were excluded, models that included blood $\mathrm{Pb}$ and $\mathrm{Hb}$ were statistically significant $(p<$ 0.01-0.05) but nevertheless explained only 23 to $28 \%$ of the variation in ALA-D activity (Table 5). No other variables met the $p<0.05$ criterion for inclusion.

\section{DISCUSSION}

\section{Lead, zinc, and cadmium concentrations}

Although several of the taxa analyzed in this study have not been investigated previously with respect to blood metals and ALA-D activity, it is nevertheless useful to compare blood-metal concentrations as a general indicator of contamination. Overall, our blood-metal concentrations were consistent with those reported by others. In studies with suckers (Pisces: Catostomidae) from streams in Missouri, Montana, and Washington, USA, blood-Pb concentrations typically were 0.05 to $0.15 \mu \mathrm{g} / \mathrm{g}$ (wet wt) at reference sites and 0.6 to 2.0 $\mu \mathrm{g} / \mathrm{g}$ at sites heavily contaminated by mining and related ac- tivities $[4,16,17]$. These concentrations were bracketed by those in 2001 carp from the SR and BR. Black redhorse (Moxostoma duquesnii) from Center Creek, a SR tributary in Jasper County, Missouri, averaged 0.14 to $0.26 \mu \mathrm{g} / \mathrm{g}$ [4] in 1981 . These latter values are nearly identical to blood-Pb concentrations in SR carp collected in 2001 (Fig. 4, Table 4). Blood$\mathrm{Pb}$ concentrations in carp from the $\mathrm{BR}(3.1-3.7 \mu \mathrm{g} / \mathrm{g})$ were also nearly identical to maximum concentrations in BR suckers collected in 1981 [17], and those in carp from LB (mean = $0.04 \mu \mathrm{g} / \mathrm{g}$ ) were similar to concentrations in suckers and other species collected previously from reference streams in Missouri $[4,16]$.

Blood- $\mathrm{Pb}$ concentrations in centrarchids from Oklahoma also were similar to those reported by previous studies. Concentrations averaged $0.03 \mu \mathrm{g} / \mathrm{g}$ in longear sunfish (Lepomis megalotis) collected from an uncontaminated BR site in 1980 and 0.4 to $0.9 \mu \mathrm{g} / \mathrm{g}$ at tailings-contaminated sites [22]. Our reference bass contained slightly lower concentrations (0.01$0.02 \mu \mathrm{g} / \mathrm{g}$ ) than reference longear sunfish from the BR, whereas those in largemouth bass and crappie from Oklahoma were about the same (0.01-0.05 $\mu \mathrm{g} / \mathrm{g}$; Fig. 4). However, blood-Pb concentrations in spotted bass from the SR were greater $(0.08-$ $0.10 \mu \mathrm{g} / \mathrm{g}$ ) than those in reference longear sunfish. Concentrations in largemouth and spotted bass obtained from the BR in 2001 also were greater $(1.1-2.0 \mu \mathrm{g} / \mathrm{g}$ ) than those in longear sunfish collected from contaminated reaches in 1980 [22].

Blood-Zn concentrations in carp from Oklahoma also were similar to those in suckers collected from Center Creek in 1989 [4], which were all slightly greater than those in suckers from even the most-contaminated streams in eastern Missouri sampled in 1981 and 1989 [4,17]. However, the 2001 blood-Zn concentrations in carp from the BR $($ mean $=9.3 \mu \mathrm{g} / \mathrm{g}$ ) were similar to previously reported values for BR suckers.

In contrast to $\mathrm{Pb}$ and $\mathrm{Zn}$, blood-Cd concentrations in carp from the Oklahoma sites were lower than those in suckers from the BR and other mining-affected streams in eastern Missouri, as also was true of suckers collected from Center Creek in 1989 [4,16,17]. Blood $\mathrm{Zn}$ and Cd concentrations in carp from LB (mean $=7.5 \mu \mathrm{g} / \mathrm{g}$ ) also were about the same as those in suckers and other species from reference streams in Missouri $[4,17]$. Only $\mathrm{Pb}$ was measured in longear sunfish blood by Dwyer et al. [22], so there is no suitable basis against which to compare our blood- $\mathrm{Zn}$ and $-\mathrm{Cd}$ concentrations in bass and crappie.

\section{Iron, hemoglobin, and ALA-D activity}

Blood $\mathrm{Fe}$ and $\mathrm{Hb}$ concentrations were highly correlated across the locations and species sampled, and the relation between them was consistent with the structure of $\mathrm{Hb}$ (Fig. 2, Table 5). To our knowledge, no studies have compared $\mathrm{Hb}$ measured with the HemoCue to traditional laboratory methods (e.g., [23]) in fish. In humans, carboxyhemoglobin has been reported to cause the instrument to overestimate $\mathrm{Hb}$ [29]. The strong correlation between $\mathrm{Hb}$ and blood Fe (Fig. 2, Table 5) suggests that the HemoCue accurately measures Hb concentrations in fish blood collected and analyzed in the manner reported here.

It always is difficult to compare enzyme activities among investigations because variations in fish acclimation temperature, whether or not activity is standardized (to $\mathrm{Hb}$, hematocrit, etc.), and such assay-related variables as incubation temperature, $\mathrm{pH}$, and substrate concentration may be reflected as differences in enzyme activity. In addition, ALA-D activity 
varies considerably among fish taxa $[4,11,12,16]$. Consequently, enzyme activity typically is compared to appropriate reference or control values generated independently within each study. In wildlife, 50\% ALA-D inhibition relative to relevant reference or control activity is considered evidence of injury associated with exposure to environmental $\mathrm{Pb}$ [30]. In our study, ALA-D activity averaged $1.8 \mathrm{nmol} \mathrm{PBG} / \mathrm{mg} \mathrm{Hb} / \mathrm{h}$ in reference channel catfish (commercially obtained and laboratory-raised) but only $0.78 \mathrm{nmol} \mathrm{PBG} / \mathrm{mg} \mathrm{Hb} / \mathrm{h}$ at site 1 (48\% of reference) and $0.58 \mathrm{nmol} \mathrm{PBG} / \mathrm{mg} \mathrm{Hb} / \mathrm{h}$ (32\% of reference) at site 2 (Table 3 ). Activity also was reduced, but by $<50 \%$, in channel catfish from the other Oklahoma sites. In the only other field study conducted with channel catfish, ALA-D activity was not detected in fish collected either upstream or downstream of a $\mathrm{Pb}$ smelter [16]. Collectively, these results indicate that the normal level of ALA-D activity is lower in channel catfish than in other species and that inhibition occurs at lower $\mathrm{Pb}$ concentrations (Fig. 4).

Compared to laboratory-raised reference largemouth bass (mean $=5.25 \mathrm{nmol} \mathrm{PBG} / \mathrm{mg} \mathrm{Hb} / \mathrm{h}$ ), ALA-D activity also was inhibited by more than $50 \%$ in largemouth and spotted bass from the $\mathrm{BR}$ (mean $=1.52$ and $1.96 \mathrm{nmol} \mathrm{PBG/mg} \mathrm{Hb} / \mathrm{h}$, respectively) but not on average in either species of bass from any of the Oklahoma sites (Table 3). The results for bass confirm earlier studies that showed $\geq 50 \%$ inhibition in other taxa collected from contaminated reaches of the BR [4,17,22]. Nevertheless, it is important to note that no reference spotted bass were available for comparison. Mean ALA-D activity in crappie averaged $3.25 \mathrm{nmol} \mathrm{PBG} / \mathrm{mg} \mathrm{Hb} / \mathrm{h}$ at site 3 but only 1.92 nmol PBG/mg Hb/h at site 5, a difference of $41 \%$. However, fish of some taxa collected from site 3 contained greater-thanexpected concentrations of metals even though the site is upstream of known sources of mining-derived metals to the NR. Hence, the full impact on white crappie cannot be determined but may be $>41 \%$. No previous studies have documented ALA-D activity in crappie or Micropterus spp.

The activity of ALA-D in carp was highly variable. It was inhibited by $>50 \%$ relative to reference values (LB) at site 5 (SR), but not at other sites where blood $\mathrm{Pb}$ concentrations were greater (including BR). In addition, and in contrast to the other taxa investigated, the correlation between ALA-D activity and blood $\mathrm{Pb}$ was poor in carp, and the slope of the regression relations between these variables was small compared with other taxa (Fig. 4, Table 5). These results are consistent with a previous field study with carp [16] in which effects on ALA-D were not evident despite a wide range of $\mathrm{Pb}$ concentrations. Hodson et al. [12] also found only a weak effect of $\mathrm{Pb}$ on ALA-D activity in the closely related goldfish (Carassius auratus). Our results, as well as those of Hodson et al. [12] and Schmitt et al. [16], contradict the findings of a laboratory investigation [15] that demonstrated high sensitivity of ALA-D activity in carp to waterborne $\mathrm{Pb}$. In the laboratory study, ALA-D activity was inhibited by $\geq 50 \%$ over a range of blood-Pb concentrations spanning about 0.1 to $10 \mu \mathrm{g} / \mathrm{g}$ [15]. Our blood- $\mathrm{Pb}$ concentrations ranged from 0.03 to $0.06 \mu \mathrm{g} / \mathrm{g}$ (LB) to $3.69 \mu \mathrm{g} / \mathrm{g}$ (BR; Table 4), and, therefore, we expected a more substantial response in carp.

Schmitt et al. [16] hypothesized that the normally greater $\mathrm{Zn}$ concentrations present in wild carp relative to other fish [31] protect ALA-D from inhibition by $\mathrm{Pb}$, as has been reported in laboratory studies with other taxa (e.g., [32]). Blood-Zn differences among species were small, however (Table 4), which was consistent with the fact that most of the elevated
$\mathrm{Zn}$ burden in carp and closely related fish is localized in the foregut; concentrations in blood, liver, and other tissues are similar to those in other species [33]. Laboratory studies have demonstrated that $\mathrm{Cd}$ and $\mathrm{Hg}$ [32] can somewhat inhibit ALA$\mathrm{D}$ activity in fish, but no previous field study has documented a Cd effect on ALA-D activity. We did not measure $\mathrm{Hg}$, but elevated $\mathrm{Hg}$ concentrations in fish have not been reported in fish from the TSMD. Therefore, we have no explanation for the comparatively weak correlation between ALA-D activity and blood $\mathrm{Pb}$ in wild carp, but also are not surprised by these results in light of the many physiological differences among fishes. Many factors, including but not limited to differences in trace metal homeostasis, may be involved.

\section{Effects of lead on fish}

Effects on heme synthesis, as indicated by a $50 \%$ reduction in ALA-D activity relative to control or reference levels, have been associated with blood-Pb concentrations exceeding approximately $50 \mu \mathrm{g} / \mathrm{dL}(0.5 \mathrm{mg} / \mathrm{L})$ and varying indirectly with $\mathrm{Zn}$ in a number of fish species $[4,16,17,22]$. Largemouth and spotted bass appear to conform to this pattern (Fig. 4). In previous studies, suckers were identified as more sensitive than most taxa [16]. Our results indicate that channel catfish may be more sensitive than suckers; effects in channel catfish were evident at blood-Pb concentrations of $<0.1 \mu \mathrm{g} / \mathrm{g}$ (Fig. 4). In addition, and in contrast to the other species we investigated, the channel catfish statistical model contained a positive term for blood Zn (Table 5). Such findings have been interpreted as indicative of possible ameliorative effects of $\mathrm{Zn}$ in other taxa $[4,17,22]$, which is consistent with results in mammals indicating that $\mathrm{Zn}$ is required as a cofactor for the activation of ALA-D [19]. However, results of laboratory studies have been equivocal with respect to $\mathrm{Zn}$ activation of ALA-D in fish [32,34,35].

Although ALA-D inhibition by environmental $\mathrm{Pb}$ is welldocumented, higher-level effects in fish only have been associated indirectly with $\mathrm{Pb}$ exposure and enzyme inhibition. Behavioral changes were reported in fathead minnows ( $P i$ mephales promelas) exposed to high concentrations of $\mathrm{Pb}$ in the laboratory [36], whereas exposure of rainbow trout $(\mathrm{On}$ corhynchus mykiss) fry to more environmentally relevant concentrations inhibited ALA-D activity but caused no behavioral effects [37]. Effects on bone strength, which may lead to impaired swimming performance and increased vulnerability to predators, also were detected in wild longear sunfish at blood$\mathrm{Pb}$ concentrations of approximately $0.5 \mathrm{mg} / \mathrm{L}$ [22]. Black tail, a neurological symptom that may portend other effects, was associated with blood $\mathrm{Pb}$ of $1.7 \mathrm{mg} / \mathrm{L}$ and ALA-D inhibition of $74 \%$ in laboratory-exposed rainbow trout [13]. Stippled erythrocytes in carp [38] and spinal deformities in brook trout (Salvelinus fontinalis) [39] also have been detected in fish exposed to high $\mathrm{Pb}$ concentrations in the laboratory, as have additional sublethal effects in other fish [13,34]. Populationand community-level effects and reduced ALA-D activity were documented in two species of catfish (Pimelodidae) inhabiting a stream in Brazil contaminated by mine tailings [40]. Blood $\mathrm{Pb}$ was not measured in that study, but concentrations in fish muscle were as great as $2.97 \mu \mathrm{g} / \mathrm{g}$. These concentrations are about 10 -fold greater than those in TSMD fish but within the range reported for fish from the BR $[4,5,17,22]$.

Consistent with the findings of most other field studies of $\mathrm{Pb}$ contamination in fish, we failed to detect an effect on $\mathrm{Hb}$ or blood Fe (Fig. 3). In birds and mammals (including hu- 
mans), prolonged exposure to $\mathrm{Pb}$ ultimately results in anemia. Such effects only have been documented inconsistently in fish, however. In black bullhead (Ictalurus [Amieurus] melas), a species closely related to the channel catfish, reduced $\mathrm{Hb}$ concentrations and other hematological effects, including altered erythrocyte morphology, resulted from laboratory exposure to $0.001 \%$ lead acetate for one month [41]. Exposure of rainbow trout to $0.3 \mathrm{mg} / \mathrm{L}$ of $\mathrm{Pb}$ in water also reduced ALA-D activity and $\mathrm{Hb}$ concentrations [42], whereas similar $\mathrm{Pb}$ concentrations inhibited ALA-D activity but caused no hematological changes in the European eel (Anguilla anguilla) [43]. In the gray mullet (Mugil auratus), both $\mathrm{Hb}$ and ALA-D activity were reduced by exposure to $\mathrm{Pb}[14]$.

Previous field studies documenting ALA-D inhibition in fish also have been inconsistent with respect to effects on $\mathrm{Hb}$. In Missouri streams contaminated by mine tailings, no effects on $\mathrm{Hb}$ were noted despite 50 to $60 \%$ ALA-D inhibition relative to reference sites in several species $[4,17,22]$. Both greater and lesser $\mathrm{Hb}$ concentrations were found in several species of whitefish (Salmonidae) collected from $\mathrm{Pb}$-contaminated lakes in Norway despite the fish having only 12 to $13 \%$ of reference ALA-D activity [10]. Effects on $\mathrm{Hb}$ in fish collected from streams contaminated by $\mathrm{Pb}$ smelters were inconsistent [16]. Collectively, these findings support the widely held belief that, although ALA-D is very sensitive to inhibition by $\mathrm{Pb}$, the process catalyzed by this enzyme is not a rate-limiting step in the synthesis of heme by fish. It also is important to note that $\mathrm{Hb}$ concentrations and other endpoints traditionally used to assess fish blood (e.g., cell counts, hematocrit) are relatively crude $[16,44]$. More sensitive techniques have demonstrated Cd effects on erythron status in laboratory studies [44], but to date no thorough study of $\mathrm{Pb}$ effects on erythropoeisis in fish has been reported.

\section{CONCLUSION}

We documented elevated blood-metal concentrations and well-defined negative statistical relations between blood- $\mathrm{Pb}$ concentrations and ALA-D activity in bass and catfish from the TSMD. Relations in carp and crappie were not as evident. These findings and those of previous studies indicate that $\mathrm{Pb}$ and other metals from historical mining activity in the TSMD have been transported to the SR and NR and accumulated by aquatic organisms. Within the TSMD, metal concentrations generally were greater in fish from the SR than the NR, but there was considerable variability within and among sites. Overall, blood-Pb concentrations in TSMD fish exceeded reference concentrations but were lower than those from the BR and other historical mining areas in the United States and elsewhere. Nevertheless, ALA-D activity was inhibited by more than $50 \%$ in catfish from several TSMD sites, which is evidence that $\mathrm{Pb}$ is both bioavailable and active biochemically. Consistent with previous investigations, neither $\mathrm{Hb}$ nor blood$\mathrm{Fe}$ concentrations were affected over the range of blood-Pb concentrations detected, further confirming the widely held belief that the inhibition of ALA-D does not limit heme synthesis in fish. However, and as noted, more sensitive indicators of erythron status and erythropoeisis [44] eventually may demonstrate otherwise. In addition, the biomarkers chosen for this investigation (erythrocyte ALA-D activity, $\mathrm{Hb}$, and blood $\mathrm{Fe}$ ) were selected because of the well-known effects of $\mathrm{Pb}$ on heme synthesis and Fe metabolism $[8,20]$. No effort was made to document direct effects of $\mathrm{Cd}, \mathrm{Zn}$, or other contaminants, which could include metallothionein induction, lipid peroxi- dation, increased macrophage aggregate numbers and hyperplasia in the kidney, other histopathological lesions in the brain, liver, and kidney, and effects on reproductive biomarkers [45-48]. Future studies in the TSMD, therefore, should include endpoints diagnostic of exposure to $\mathrm{Cd}, \mathrm{Zn}$, and other metals in combination with $\mathrm{Pb}$ and seek to document higher-level effects in fish. In addition, the heme synthetic pathway is lengthy and complex, and can be affected at many points by a variety of pollutants beyond those discussed in this article [49]. Future research, therefore, should investigate the effects of metals on heme synthesis and erythropoeisis in a more thorough and holistic manner.

Acknowledgement-This study was conducted jointly by the U.S. Geological Survey (USGS) and the U.S. Fish and Wildlife Service (USFWS) through Interagency Agreement 20181-01-N756A, which was facilitated by D. Martin. D. Heckathorne and S. Dudding coordinated the collection of fish from the Oklahoma sites. Logistical and field support were provided by J. Dalgarn of the U.S. Bureau of Indian Affairs (Miami, OK). D. Sappington of the Quapaw Tribe of Oklahoma also assisted in the field. Fish from Long Branch Lake and the Big River were obtained with the assistance of M. Reed and M. Anderson of the Missouri Department of Conservation. T. May, A. Donahue, J. Arms, M. Annis, and J.A. Allert of our laboratory assisted in various aspects of the study. M. Ellersieck of the University of Missouri (UM) and P. Haverland provided statistical advice, and R. Lea prepared the map. The use of trade names does not constitute government endorsement.

\section{REFERENCES}

1. Spruill TB. 1987. Assessment of water resources in lead-zincmined areas in Cherokee County, Kansas, and adjacent areas. Water Supply Paper 2268. U.S. Geological Survey, Lawrence, KS.

2. May TW, Wiedemeyer RH, Brumbaugh WG, Schmitt CJ. 1997. The determination of metals in sediment pore waters and in $1 \mathrm{~N}$ HCl-extracted sediments by ICP-MS. At Spectrosc 18:133-139.

3. Yoo JL, Janz M. 2003. Tissue-specific HSP70 levels and reproductive physiological responses in fish inhabiting a metal-contaminated creek. Arch Environ Contam Toxicol 45:110-120.

4. Schmitt CJ, Wildhaber ML, Hunn JB, Nash T, Tieger MN, Steadman BL. 1993. Biomonitoring of lead-contaminated Missouri streams with an assay for erythrocyte $\delta$-aminolevulinic acid dehydratase (ALA-D) activity in fish blood. Arch Environ Contam Toxicol 25:464-475.

5. Czarneski J. 1985. Accumulation of lead in fish from Missouri streams affected by lead mining. Bull Environ Contam Toxicol 34:736-745

6. Neuberger JS, Mulhall M, Pomatto MC, Sheverbush J, Hassenein R. 1990. Health problems in Galena, Kansas: A heavy metalmining Superfund site. Sci Total Environ 94:261-272.

7. Wildhaber ML, Allert AL, Schmitt CJ, Tabor VM, Mulhern D, Powell KL, Sowa SP. 2000. Natural and anthropogenic influences on the distribution of the threatened Neosho madtom in a Midwestern warm water stream. Trans Am Fish Soc 129:243-261.

8. Joselow MM. 1980. Blood-zinc and-lead poisoning. In Nriagu JO, ed, Zinc in the Environment, Part II, Health Effects. John Wiley, New York, NY, USA, pp 171-181.

9. Warren MJ, Cooper JB, Wood SP, Shoolingen-Jordan PM. 1998. Lead poisoning, heme synthesis, and 5-aminolevulinic acid dehydratase. Trends Biochem Sci 23:217-221.

10. Haux C, Larsson A, Lithner G, Sjobeck ML. 1986. A field study of physiological effects on fish in lead-contaminated lakes. Environ Toxicol Chem 5:283-288.

11. Hodson PV. 1976. $\delta$-Aminolevulinic acid dehydratase activity of fish blood as an indicator of a harmful exposure to lead. J Fish Res Board Can 33:268-271.

12. Hodson PV, Blunt BR, Spry J, Austen K. 1977. Evaluation of erythrocyte $\delta$-aminolevulinic acid dehydratase activity as a shortterm indicator in fish of a harmful exposure to lead. J Fish Res Board Can 34:501-508.

13. Hodson PV, Blunt BR, Jensen D, Morgan S. 1979. Effect of fish age on predicted and observed chronic toxicity of lead to rainbow trout in Lake Ontario Water. J GT Lakes Res 5:84-89. 
14. Krajnovi-Ozreti M, Ozreti B. 1980. The ALA-D activity test in lead-exposed grey mullet Mugil auratus. Mar Ecol Prog Ser 3: 187-191.

15. Nakagawa H, Nakagawa K, Sato T. 1995. Evaluation of erythrocyte $\delta$-aminolevulinic acid dehydratase activity in the blood of carp Cyprinus carpio as an indicator in fish and water lead pollution. Fish Sci 61:91-95.

16. Schmitt CJ, Caldwell CA, Olsen B, Serdar D, Coffey M. 2002. Inhibition of erythrocyte $\delta$-aminolevulinc acid dehydratase (ALAD) activity in fish from waters affected by smelters. Environ Monit Assess 77:99-119.

17. Schmitt CJ, Dwyer FJ, Finger SE. 1984. Bioavailability of $\mathrm{Pb}$ and $\mathrm{Zn}$ from mine tailings by erythrocyte $\delta$-aminolevulinic acid dehydratase (ALA-D) activity in suckers (Pisces: Catastomidae). Can J Fish Aquat Sci 41:1030-1040.

18. Henny CL, Blus LJ, Hoffman DJ, Sileo L, Audet DJ, Snyder MR. 2000. Field evaluation of lead effects on Canada geese and mallards in the Coeur d'Alene Basin, Idaho. Arch Environ Contam Toxicol 39:97-112.

19. Goldstein DH, Kneip TJ, Rulon VP, Cohen N. 1975. Erythrocytic aminolevulinic acid dehydratase (ALA-D) activity as a biologic parameter for determining exposures to lead. J Occup Med 17: $157-162$.

20. Wigfield DC, Wright SC, Chakrabarti CL, Karwowska R. 1986. Evaluation of the relationship between chemical and biological monitoring of low-level lead poisoning. J Appl Toxicol 6:231235

21. Overmann SR, Krajicek JJ. 1995. Snapping turtles (Chelydra serpentina) as biomonitors of lead contamination of the Big River in Missouri's Old Lead Belt. Environ Toxicol Chem 14:689-695.

22. Dwyer FJ, Schmitt CJ, Finger SE, Mehrle PM. 1988. Biochemical changes in longear sunfish, Lepomis megalotis, associated with lead, cadmium, and zinc from mine tailings. J Fish Biol 33:307317.

23. Vanzetti G. 1966. An azide-methemoglobin method for hemoglobin determination in blood. J Lab Clin Med 67:116-126.

24. Whyte JJ, Jung RE, Schmitt CJ, Tillitt DE. 2000. Ethoxyresorufin$O$-deethylase (EROD) activity in fish as a biomarker of chemical exposure. Crit Rev Toxicol 30:347-570.

25. Granick S, Sassa S, Granick JL, Levere RD, Kappas A. 1972. Assays for porphyrins, $\delta$-aminolevulinic-acid dehydratase, and porphyrinogen synthetase in microliter samples of whole blood: Applications to metabolic defects involving the heme pathway. Proc Natl Acad Sci USA 69:2381-2385.

26. Statistical Analysis System Institute. 1999. SAS/STAT ${ }^{\circledR}$ User's Guide, Ver 8. Cary, NC, USA.

27. Grujic-Injac B, Braunitzer G, Stangl A. 1980. Hemoglobins, XXXV: The sequence of the beta-A and beta-B chains of the hemoglobins of the carp (Cyprinius carpio L). Hoppe-Seyler's Z Physiol Chem 361:1629-1639.

28. Ricker WE. 1973. Linear regressions in fishery research. J Fish Res Board Can 30:409-434.

29. Shepherd AP, Seinke JM, Gong AK. 2000. Effects of carboxyhemoglobin on hemoglobinometers. Clin Chem 46:586-587.

30. U.S. Department of the Interior. 1987. Type-B technical information document: Injury to fish and wildlife species. CERCLA 301 Project. Washington, DC.

31. Schmitt CJ, Zajicek JL, May TW, Cowman DF. 1999. National Contaminant Biomonitoring Program: Concentrations of organochlorine chemical residues and elemental contaminants in U.S. freshwater fish, 1976-1986. Rev Environ Contam Toxicol 162: 43-104.

32. Rodrigues AL, Bellinaso ML, Dick T. 1989. Effect of some metal ions on blood and liver delta-aminolevulinate dehydratase of $\mathrm{Pi}$ melodus maculatus (Pisces: Pimelodidae). Comp Biochem Physiol B 94:65-69.
33. Sun L-T, Jeng S-S. 1998. Comparative zinc concentrations in tissues of common carp and other aquatic organisms. Zool Stud 37:184-190.

34. Gonzalez OJ, Fernandez J, Martin M. 1987. Inhibition of trout (Salmo gairdneri R.) PBG-synthase by some metal ions ( $\mathrm{Mg} 2+$, $\mathrm{Pb} 2+, \mathrm{Zn} 2+$ ). Comp Biochem Physiol 86:163-167.

35. Conner EA, Fowler BA. 1994. Biochemical and immunological properties of hepatic $\delta$-aminolevulinic acid dehydratase in channel catfish (Ictalurus punctatus). Aquat Toxicol 28:37-52.

36. Webber DN, Russo A, Seale DB, Spieler RE. 1991. Waterborne lead affects feeding abilities and neurotransmitter levels of juvenile fathead minnow Pimephales promelas. Aquat Toxicol 21: 71-80.

37. Burden VM, Sandheinrich MB, Caldwell CA. 1998. Effects of lead on the growth and $\delta$-aminolevulinic acid dehydratase activity of juvenile rainbow trout, Oncorhynchus mykiss. Environ Pollut 101:285-289.

38. Beriti T, Zibar-iki J, Prpi-Maji D, Tudor M. 1980. Some morphological and hematological parameters of abnormal lead absorption in fish. In Branica M, Zdenka K, eds, Lead in the Marine Environment. Pergamon, Oxford, UK, pp 263-269.

39. Holcombe GW, Benoit DA, Leonard EN, McKim JM. 1976. Long-term effects of lead exposure on three generations of brook trout (Salvelinus fontinalis). J Fish Res Board Can 33:17311741

40. Moraes M, Gerhald P, Andersson L, Shimada H, Sturve J, Rauch S, Molander S. 2002. Assessing ecological risks of abandoned lead mines to aquatic fauna. ESA-Report 2002:3. Chalmers University of Technology, Department of Environmental Sytems Analysis, Göteborg, Sweden.

41. Garavini C, Martelli P. 1979. Effect of lead acetate on erythropoiesis and ultrastructural changes of erythroblasts in the catfish Ictalurus melas (Rafinesque) (Siluriformes Ictaluridae). Monit Zool Ital (NS) 13:83-93.

42. Haux C, Larsson A. 1982. Influence of inorganic lead on the biochemical blood composition in the rainbow trout, Salmo gairdneri. Ecotoxicol Environ Saf 6:28-34.

43. Santos MA, Hall A. 1990. Influence of inorganic lead on the biochemical blood composition of the eel, Anguilla anguilla L. Ecotoxicol Environ Saf 20:7-9.

44. Houston AH. 1997. Review: Are the classical hematological variables acceptable indicators of fish health? Trans Am Fish Soc 126:879-894.

45. Farag AM, Woodward DF, Brumbaugh WG, Goldstein JN, MacConnell E, Hogstrand C, Barrows FT. 1999. Dietary effects of metals-contaminated invertebrates from the Coeur d'Alene River, Idaho, on cutthroat trout. Trans Am Fish Soc 128:578592.

46. Farag AM, Skaar D, Nimick DA, MacConnell E, Hogstrand C. 2003. Characterizing aquatic health using salmonids mortality, physiology, and biomass estimates in streams with elevated concentrations of arsenic, cadmium, copper, lead, and zinc in the Boulder River watershed, Montana. Trans Am Fish Soc 132:450_ 467.

47. Campana O, Sarasquete C, Blasco J. 2003. Effect of lead on ALA$\mathrm{D}$ activity, metallothionein levels, and lipid peroxidation in blood, kidney, and liver of the toadfish Halobatrachus didactylus. Ecotoxicol Environ Saf 55:116-125.

48. Pereira JJ, Mercaldo-Allen R, Kuropat C, Luedke D, Sennefeleder G. 1993. Effects of cadmium accumulation on serum vitellogenin levels and hepatosomatic and gonadosomatic indices of winter flounder (Pseudopleuronectes americanus). Arch Environ Contam Toxicol 24:427-431.

49. Lorenzen A, Kennedy SW, Bastien LJ, Hahn ME. 1997. Halogenated aromatic hydrocarbon-mediated porphyrin accumulation and induction of cytochrome P4501A in chicken embryo hepatocytes. Biochem Pharmacol 53:373-384. 